\title{
The nature of mothers' work and children's schooling in Nepal: The influence of income and time effects
}

Ashish Bajracharya

Population Council

Follow this and additional works at: https://knowledgecommons.popcouncil.org/departments_sbsr-pgy

Part of the Demography, Population, and Ecology Commons, Family, Life Course, and Society Commons, Gender and Sexuality Commons, Gender Equity in Education Commons, International Public Health Commons, Maternal and Child Health Commons, and the Women's Health Commons How does access to this work benefit you? Let us know!

\section{Recommended Citation}

Bajracharya, Ashish. 2010. "The nature of mothers' work and children's schooling in Nepal: The influence of income and time effects," Poverty, Gender, and Youth Working Paper no. 21. New York: Population Council. 


\section{POVERTY, GENDER, AND YOUTH}

The Nature of Mothers' Work and Children's

Schooling in Nepal: The Influence of Income and

Time Effects

Ashish Bajracharya

WORKING PAPER NO. $21 \quad 2010$

$\mathcal{A}$ Population Council 


\section{(2) Population Council}

One Dag Hammarskjold Plaza

New York, New York 10017 USA

www.popcouncil.org

pubinfo@popcouncil.org

For information on Poverty, Gender, and Youth working papers, see www.popcouncil.org/publications/wp/index.html

This material may not be reproduced without written permission from the author.

ISSN: 1554-8538

(C) 2010 The Population Council, Inc. 


\section{The Nature of Mothers' Work and Children's Schooling in Nepal: The Influence of Income and Time Effects}

Ashish Bajracharya

Ashish Bajracharya is Fred H. Bixby Postdoctoral Fellow, Population Council, New York. E-mail: abajracharya@popcouncil.org. I am grateful to Rachel Dunifon, Daniel Lichter, Gary Evans, Donald Kenkel, Wendy Baldwin, and Sajeda Amin for their valuable comments. I am also grateful to the Central Bureau of Statistics of the Government of Nepal for furnishing the data and for technical data support. Part of this research was conducted at Cornell University and benefitted from travel grants from the Mario Einaudi Center for International Studies and from the Department of Policy Analysis and Management. An earlier version of this paper was presented at the 2008 Population Association of America Meetings, 17-19 April, New Orleans, LA. 


\begin{abstract}
This paper examines the influence of the nature of mothers' work on Nepali children's schooling outcomes. Using nationally representative cross-sectional data from the Nepal Living Standards Survey (NLSS), it analyses whether the engagement of mothers (and fathers) in nonagricultural work has significant consequences for their children's school attendance and grade attainment, compared with these consequences when parents' work is in traditional subsistence agriculture. With the high rate of female labor-force participation and the rapidly transforming workforce in Nepal, transitions into more formal and nonagricultural forms of work are expected to have significant time and income effects upon their families and children, particularly on their children's schooling, especially that of girls. Using analyses that simultaneously account for the work patterns of mothers and fathers, this study uses binary probit and ordinary least squares models to examine these relationships. Results indicate that children of parents who both work in the nonagriculture sector are significantly more likely to have attended or currently be attending school and have higher grade attainment, compared with children whose parents work in the agriculture sector. These associations do not persist, however, when income controls are added, which suggests that strong income effects may be driving these associations. No evidence of significant time effects is observed. The extended analyses in the study fail to find evidence of mediating effects of income or maternal control over resources on children's schooling. Policy implications of this research, including those for policies promoting women's economic participation and for schooling of children in Nepal, are discussed.
\end{abstract}




\section{INTRODUCTION}

Women, in developing countries, particularly mothers, have dual roles in their households as income generators and primary caregivers to their children (Leslie and Paolisso 1989; Glick and Sahn 1998; Glick 2002). Because of time limitations, these roles are more often than not at odds with each other, with significant consequences for children. As the number of women entering the labor force has risen dramatically over the past several decades, women in the developing world are increasingly compelled to juggle family and work responsibilities, much as women do in industrialized economies. The consequences of conflicts in women's responsibilities are particularly significant for children because mothers are generally considered to be the primary agents of the healthy development and survival of children in the developing world.

Global macroeconomic changes and transitions in patterns of production have prompted a significant shift in developing countries in the nature of work for both men and women from agriculture to industry, manufacturing, and services (Mehra and Gammage 1999). These changes have been of particular consequence to women. On the one hand, the transition to working in the more formal nonagricultural sectors of the economy provides women with higher wages, allowing them the resources for greater investments in their own and their children's welfare. On the other hand, this transition also forces women to work outside their homes, creating challenges for childcare. The significance of this situation is amplified in developing countries because most families live in conditions of extreme poverty. For mothers in developing countries, working in the market economy is often a necessity for family survival rather than a choice. The consequences of the nature of women's work are, therefore, relevant to the development of children.

Much of the empirical literature that examines the impact of mothers' work in developing countries has focused on its effects on children's nutrition. Women's work and the complexity of their dual roles are likely to have significant impacts on other human capital investments in children, in particular on their schooling. This study aims to address this underexamined but important issue by using household-survey data from Nepal, one of the poorest countries in the world. Nepal presents a compelling case for a study on this topic because it has among the highest rates of female labor-force participation in the developing world and, therefore, a significant number of working mothers. According to the Nepal Demographic and Health Survey (MOHP et al. 2006), around two-thirds of women aged 20 to 24 were engaged in some form of remunerative work, compared with negligible proportions in neighboring Bangladesh and in Bihar and Uttar Pradesh in India. Nepal has also undergone drastic changes in the nature of its labor force in the past several decades. In 1981, nearly 90 percent of economically active men and virtually all economically active women in Nepal were involved in agriculture. These figures had declined to around two-thirds for men and three-fourths for woman by 2001 (Tuladhar 2005). Although agriculture remains the predominant form of work in Nepal, particularly for women, the transition to nonagricultural jobs has occurred rapidly, thereby creating additional challenges to the workfamily balance for women, particularly for mothers. Together, both of these factors are likely to have significant consequences for human capital investments in children.

Raising the economic status of women through employment, particularly in formal and nonagricultural sectors of the economy, has been an important component of the development 
agenda in Nepal (UN 2006 and Nepal Poverty Reduction Strategy Paper 2006). Policies and programs within this framework have been primarily aimed at increasing women's decisionmaking power and improving their status in the household by empowering them economically through employment. Their roles in households as caregivers have largely been overlooked in development policies, however. The available research from the developing world suggests that women's employment might have significant influences on their children's wellbeing, on their health, and on their human capital investments. Such policies would benefit from a nuanced understanding of the how the nature of women's work may affect the well-being of children, a significant policy priority in its own right. This paper aims to fill the void in research conducted in Nepal concerning this topic by examining associations of the nature of women's work with the schooling outcomes of their children. Using data on men, women, and children from the Nepal Living Standards Survey (NLSS), this study seeks to examine whether mothers' nonagricultural jobs are of significant consequence to their children's schooling when compared with their work in the agriculture sector. This study will be among the first to address these important questions in Nepal using contemporary national data.

\section{BACKGROUND}

\section{Conceptual framework}

Studies on the impact of mothers' employment on their children's lives has generally has followed theoretical models that are based on Becker's (1965) "new household economics," which includes the time of the household member as a major input in the household-production function. It assumes that household members draw utility not only from market goods and goods produced in the household but also from their leisure time. It posits that women exhibit rational behavior in making choices that have economic and human capital consequences for members of their household, particularly children. Thus, women are assumed to make their decisions about whether to participate in market work or in nonagricultural sectors of the economy based on which activity has a higher perceived value to them and for their families (Vial and Muchnik 1989). In the developing world, however, where women's autonomy and agency are severely limited, these decisions are unlikely to be altogether under their control and are much more likely to be based on the perceived relative importance of their caregiving work or market work for their families and their households as a whole. Whether the decision for women to work is made at the household or individual level, maternal work is likely to have opposing time and income effects on the well-being of children. On the one hand, a mother's employment in the nonagricultural sector may result in positive income effects from additional resources that become available to her with the higher income that she earns from market work. These resources can be invested in activities that enhance her children's nutrition, health status, schooling, or other human capital investments. On the other hand, if the mother's work outside the home reduces the time she has available for childcare or other domestic work, it can have negative time effects for her children's well-being. If mothers have to leave their homes in order to engage in market work, the burden of care often falls on substitute caregivers, who, in developing countries, are often older daughters (Joekes 1989). If older daughters are chosen as

substitute caregivers for their younger siblings, the effects may be detrimental to both the 
caregiver and the younger children: the older daughter's schooling opportunities may be impeded and the quality of care available to her young siblings lowered. Thus, as Glick (2002) asserts, a mother's decision to work, or more specifically to work in a particular sector, is intrinsically tied to the perceived value of that work for her family. Whether the consequences of her decision are positive or negative for her children depends ultimately on which of the effects is larger.

Decisions about women's work may also depend on the nature and the level of their husbands' work. Women with high-earning and high-status husbands may derive lower value from their market work than they would from household activities such as caring for their children, thus reducing the necessity that they work outside the home. Households with limited means or with a lower-status husband may require that the wife seek market work. In such a case, the value gained from working, in terms of income, may exceed the value gained from household-based activities, particularly when the potential benefits for children from increased monetary resources are considered. In some instances, both parents may decide to engage in market work to generate higher incomes in order to augment the benefit to their children and to the welfare of their households. They may choose to pay for alternative care arrangements, when available, or depend on kinship networks for childcare. Thus, the nature of mother's participation in the labor force is a result of an intersection of a complex set of factors, the effects of which are likely to manifest in their children's outcomes. In the following section, I review the literature that addresses mothers' work and children's outcomes in schooling in the developing world that primarily draws from this framework.

\section{MOTHERS’ EMPLOYMENT AND CHILDREN'S SCHOOLING}

As noted above, the literature from the developing world that addresses issues of mothers' employment and children's well-being is almost exclusively focused on children's nutrition. This sizeable literature, reviewed in Glick (2002) (see Leslie 1989 for a review of the earlier literature), mainly examines the associations between the participation of mothers in the labor force and anthropometric nutritional outcomes such as height-for-age and weight-for-age of children typically younger than three that are used as direct proxies for their health. Over the years, this research has steadily expanded into examining the impacts of more subtle constructs of women's economic participation, including the nature of their work (that is, work sector) or the level of their work on their children's nutrition, increasingly by means of rigorous multivariate analyses (see Glick 2002 for a review of literature that relates mothers' work sector and children's nutrition). Although in a majority of cases, the income and time effects described above are observed to be acting in expected directions, the literature is unable to establish broadly consistent results, which may be a testament to the complexity of these interrelationships. Nonetheless, the literature on mothers' work and children's health and nutrition is extensive and growing.

The literature on the effects of mothers' employment on other human capital investments in their children, particularly for schooling and educational outcomes, is limited, however, although a substantial literature exists on the determinants of schooling in the developing world (reviewed in Strauss and Thomas 1995). Research that explicitly relates mothers' employment or

their patterns of work to investments in their children's schooling is notably sparse. Some 
studies, however, have begun to address these issues in the developing world, primarily focusing on mothers' participation in the labor force and its relationship to their children's, particularly girls', schooling. This research remains in its infancy, and thus more detailed aspects of maternal work, such as work sector, have not been addressed adequately.

In this literature, time and income effects of women's work again emerge as significant determinants of their children's schooling outcomes. Although they occur simultaneously, whether the impact of women's work outside the home is beneficial and detrimental to their children ultimately depends on which of the two effects is stronger. In terms of income effects, studies suggest that investments in education are almost always positively associated with additional resources and income (Behrman and Knowles 1999). Thus, controlling for effects of time allocation, the added income in the household resulting from the mother's participation in the labor force can be expected to be positively associated with the likelihood that the child will be enrolled in school (Glick 2002). If the mother's preferences, compared with the fathers' preferences, favor investing in the children, as many researchers have suggested (see Glick 2002), the benefits from the mothers' income to the schooling outcomes of the children are likely to be larger than those from other sources of household income. This suggestion implies that the more control the mother has over her income and household resources, the more likely she is to invest in her children's schooling and other aspects of human capital. Studies in the nutrition literature (Hoddinott and Haddad 1994; Glick and Sahn 1998) have noted such positive associations for children's nutritional status and health outcomes. Evidence to support this hypothesis exists in the current literature. For example, Duraisamy and Malathy (1991) and Duraisamy (1992) find that mothers' asset ownership is positively related to their childrens' likelihood of being enrolled in school. Thomas (1993) finds, similarly, that household- budget allocation for human capital investments in children, such as in their health and education, also rises when the income is controlled by the mother.

The sex of children is an important consideration for household decisions concerning children's schooling as well, particularly in developing countries where large gender gaps in education persist, as a result of gender inequities that are deeply embedded in social and institutional structures. Although the income effects of womens' labor-force participation is likely to be of consequence to the schooling of both boys and girls, previous research suggests that mothers' work might be more consequential for girls than for boys. For example, Glick and Sahn (2000) found that mothers' education benefitted only girl's schooling in Guinea, whereas fathers' education benefitted children of both sexes. Although this finding is not universal, Glick (2002) asserts that educated mothers and their preferences for schooling girls ensure increased resources, including investments of their earnings, for girls as they command higher bargaining power in the household, compared with uneducated women.

Although these findings reflect the income effects of mother's work on their children's schooling, time effects of maternal employment may affect children in the opposite direction, again showing stronger effects for girls. Girls in developing countries are traditionally chosen as substitute caregivers for younger siblings and are required to perform other household work when the mother works outside the home. When girls are compelled to take on these responsibilities, they experience a greatly diminished chance of being enrolled in school and suffer lower educational attainment. A broad literature has identified girl's substitute caregiving 
activities as a major hindrance to their school enrollment in developing countries (Nieves 1981; Engle et al. 1985; Deolalikar 1998; Glick and Sahn 2000). Glick and Sahn (2000) found that in urban Guinea, the number of siblings younger than five significantly reduced school enrollment for girls and lowered their grade attainment while not affecting boys in the same way. Deolalikar (1998) finds similar negative associations of the number of siblings with girls' primary- and secondary-school enrollment from a sample in Kenya. These effects appear to persist even after controlling for the effects of income.

Much of the literature that examines the effect of mothers' work effort on their children's schooling appears to show a common pattern, where, despite the presence of a clear time-related conflict between women's choice of entering the labor force and girls' access to education, income effects appear to dominate. According to Glick (2002), although time-allocation effects and substitute caregiving are seen to be negatively associated with girls' schooling, women seem to avoid these effects when their incomes are high enough to afford them other forms of childcare that do not penalize their daughters (Papart 1990). Household income may, therefore, have a positive mediating role in the relationship between maternal work and girls' schooling and educational outcomes, and income effects are likely to be stronger than time effects in determining these outcomes for children. Conversely, negative mediating effects of income have also been observed in some studies (for example, Basu 1993 and Lokshin et al. 2000). In these studies, conducted in urban India and in poor neighborhoods in Kenya, girls' schooling did not improve despite increases in women's wage rates. In these especially poor settings, working women earning higher wages likely perceive the benefits of using their daughters as substitute caregivers as outweighing the potential benefit from investing in their schooling, resulting in such perverse effects. Such income effects thus warrant special attention in the research that examines schooling outcomes for children in developing countries.

\section{SETTING AND RATIONALE}

The effects on children's schooling of their mothers' work sector are examined here for Nepal. With a gross national income (GNI) per capita of \$US1,630 (purchasing power parity) in 2006, Nepal is considered to be one of the poorest countries in the world, and it presents a compelling case for any study related to gender, development, or children's well-being, and especially one related to a nexus of the three. ${ }^{1}$ The status of women in Nepal compared with that of men has historically been extremely low, particularly in the terms of their access to education, knowledge, economic resources, political agency, and involvement in decisionmaking processes. As a result, both governmental and nongovernmental policy initiatives have prioritized women's issues in their development agendas, focusing primarily on health, education, and rights. These programs and policies aim to reduce maternal mortality and fertility rates and increase women's access to health care and their literacy rates, as well as girls' school-enrollment rates. Policymakers have attributed women's low status, particularly with regard to their access to economic resources and decisionmaking power, to their heavy reliance on subsistence agriculture. Recently, development strategies have begun to incorporate formal economic participation and employment for women as a significant part of policy objectives. With approximately three-fourths of economically active women still working in subsistence 
agriculture, these policies are potentially important agents for improving women's economic status in Nepal. These strategies, aimed at generating higher wages and earnings for women through nonagricultural employment, increasing their access to credit, and engendering their active participation in decisionmaking processes, are important components of the Nepal's most recent development plans.

Several other factors make the situation in Nepal particularly relevant for a study on work-sector effects on children's schooling. First, although women's status in Nepal is low generally, Nepali women are significantly involved in the economic sphere, even at younger ages, compared with their South Asian counterparts. Some comparative figures are shown in Table 1. According to a standardized measure of women's economic activities outside of the home from the 2006 DHS, 48 percent of adolescent girls aged 15 to 19 and 59 percent of young women aged 20 to 24 were economically active in Nepal. These proportions are significantly higher than work-force-participation rates among women in comparable neighboring regions such as Bangladesh and the North Indian state of Bihar, where economic activity among 15-19year-old girls is as low as 10 percent and 15 percent, respectively, and for women aged 20 to 24, 17 percent and 12 percent, respectively. In fact, the 2006 statistics for women's labor-force participation in Nepal was the highest for this standardized measure among all countries where DHS surveys were conducted. A significant proportion of women who are employed outside their homes are also mothers. This change in the makeup of the labor force has also substantially transformed the dynamics of the gendered division of labor in Nepalese households as women have taken on increasingly important economic roles while remaining responsible for childcare and household work. The nature of remunerative work has been drastically transformed in the past 30 years in Nepal as well, particularly for women. These changes are evident in the figures from the Central Bureau of Statistics (2003) shown in Figure 1, which show significant declines in the proportion of the population working in agriculture between 1981 and 2001. Agricultural work which provided the livelihoods of virtually all economically active females in Nepal in 1981 (96 percent) had declined to 91 percent in 1991 and, drastically, to 73 percent in 2001. Changes in men's work have been dramatic as well: only 60 percent of men worked in agriculture in 2001, compared with 90 percent in 1981. This decrease is attributed to fast rates of development and modernization and to the adoption of new information and technologies that Nepal has experienced in the past three decades. The question arises: If the predictions of the time and income effects of women's changed role in the labor force operate in expected directions, will children's schooling, particularly that of girls, be affected?

In education, which had undergone significant advancement during the past several decades in Nepal, progress has stagnated in the past ten years. The Nepal Living Standards Survey (NLSS), the data source used in this study, showed that only 72 percent of primaryschool-aged children were enrolled in schools the same year. Furthermore, girls remain unenrolled at disproportionate levels, compared with boys. According to the most recent national data available from the DHS (2006), nearly 12 percent of girls aged 10 to 14 and approximately 21 percent of girls aged 15 to 19 had never been to school. More than half of children, both girls and boys, who enroll in school do not complete the primary level. According to a recent report from the UNDP (2006), at this current rate of progress, Nepal will fall behind on the goal of attaining universal primary education for all children by 2015 as outlined in the Millennium 
Development Goals. Education and specifically, the goal of universal primary education, remains a top government policy priority, but has suffered recent setbacks. The programs and policies launched to address this stagnation have tended to attribute much of it to socioeconomic forces, caste and ethnic discrimination, and more recently to the debilitating Maoist conflict. These discussions have, however, generally ignored the implications that significant changes in the female labor force may have had an impact on girls' schooling.

A survey of the relevant literature revealed no studies that have addressed the implications for children's schooling of the nature of maternal work during the recent transition from agriculture to other employment in Nepal. This lack of research is unsurprising, because the global literature on this topic is in its infancy. Only a few empirical studies have examined implications of maternal employment patterns or type of work for children's well-being in developing-country settings, and most concern children's nutritional status (for example, Glick and Sahn 1998 [Guinea]; Chutikul 1986 [Thailand]; and Wolfe and Behrman 1982 [Nicaragua]). In Nepal, only a handful of studies have addressed the impact of maternal employment on children's well-being. Three studies, Acharya and Bennett (1983); Levine (1988); and Paolisso et al. (2002) are of particular note. Among them, Levine and Paolisso and colleagues address interventions or are based on smaller samples, and are largely qualitative. Paolisso and colleagues (2002) examine the time-allocation implications of a cash-crop-technology intervention program that targeted a small rural sample of Nepali women with children. They find that women who participated in this intervention, which was designed specifically to be home based and compatible with childcare, did not have to sacrifice as much time with their children as they did when they worked at agricultural jobs or in livestock tending. Levine (1988) examined the compatibility of mountain agriculture with childcare, finding that the intensive systems of cultivation employed in these areas coupled with difficulties arising because of the terrain, decreased the time women spent with their children and was detrimental to their infantfeeding schedule. Thus, agricultural work that is located in difficult terrain and that is of high intensity may not be compatible with childcare, despite the widely accepted assumption that agriculture-based work is more compatible with childcare in many settings. A World Bank study by Acharya and Bennett (1983) examined the impact of women's market work on their status and decisionmaking roles in the household in rural Nepal using multivariate analyses. The authors found that women's increased income from work outside the home raised their status in the household and enhanced their involvement in household decisionmaking. Domestic work decreased their status. This study also showed that women were likely to spend their earned income on investments in their children's well-being.

\section{DATA}

Data for this study are drawn for the 1995-96 and 2003-04 waves of the NLSS, a nationally representative, multitopic household survey conducted by the Central Bureau of Statistics (CBS) of the Government of Nepal in conjunction with the World Bank. This survey follows the World Bank's Living Standards Measurement Survey (LSMS) methodology and uses a two-stage stratified sampling procedure. The NLSS I collected data from 3,373 households from 274 primary sampling units (PSU) in 1995-96 from nearly all of the 75 districts in Nepal. Similarly, the NLSS II 
enumerated data from 3,912 households from 326 PSUs in 2003-04. In addition, 962 households were chosen in the NLSS I as panel households and were reinterviewed in the NLSS II (CBS 2004). Only cross-sectional households are used in the analyses presented here.

The NLSS is among the most comprehensive household surveys ever conducted in Nepal and covers a wide range of topics, including demographic characteristics of respondents and their households, indicators of income, consumption, employment, educational attainment, marriage, maternity history, health status, remittances, quality and access to facilities, and agricultural and nonagricultural production. In particular, the detailed data on men's and women's employment, their earnings, and type of work make the NLSS a particularly suitable dataset for the analyses presented here.

The sample for this study is comprised primarily of children of school-going age, (6 to 19 years), from both cross-sectional waves of the NLSS, who are born to income-earning parents. Analyses are conducted on pooled data from both waves, resulting in a sample of 3,745 children from the NLSS I and 3,607 children from the NLSS II, for a combined sample of 7,352 children. In light of the research questions addressed in this study, only children of parents who both earn an income are included in the survey, that is, children of mothers and fathers who both report at least one form of economically gainful activity or employment. Children whose mothers (or in a minor number of cases, fathers) who report only domestic activities (that is, activities that produce no economic or monetary benefit to the household) are thus excluded from the sample. Data come from approximately 1,800 households in each of the NLSS survey waves. The sample composition is described in detail in the results section below.

\section{MeAsures}

\section{Dependent variables}

The dependent variables in this study capture schooling outcomes of children and young people of school-going age (6-19) in Nepal. ${ }^{2}$ Schooling outcomes are measured in two domains: school enrollment and school attainment. In terms of school enrollment, two variables are measured for all children of school-going age. First, a variable indicating whether the child was ever enrolled in school is measured and coded as one if the child is attending school at the time of the survey or has ever attended a formal government or private school in the past. If the child has never attended school, the variable is coded zero. A second variable indicating the child's current school-enrollment status at the time of the survey is also measured based on whether the child was enrolled in any form of formal schooling when the interview was conducted.

Second, two measures of a child's educational attainment are also examined in the analyses. First an outcome indicating the highest grade attained by the child is measured. This measure is used in the analyses by controlling it for the age of the child, constructing a grade-forage variable, as outlined in Patrinos and Psacharopolous (1997) and Illahi (2001). This variable is constructed as follows:

$$
\text { Grade-for-age }=100 *(\text { grade attained by child } / \text { child's age }-6)
$$


Following Patrinos and Psacharopolous (1997), this variable is measured using dispersion from the age of six. ${ }^{3}$ This variable is measured for all children aged 7-19, regardless of whether or not they have ever been enrolled in school. A score of 100 on this scale indicates complete attainment or that the child is on track in terms of schooling, whereas a score of zero indicates that the child has fallen behind completely. Therefore, children who have never been enrolled in school after the age of seven have a value of zero for this variable. Children aged six, who would have a value of zero for this variable even if they were on track in their schooling, are therefore, excluded for this variable. In addition to capturing school attainment while controlling for age, this variable also effectively captures nonenrollment of children. In the small number of cases in which children are ahead in school for their age and have a score higher than 100, the scores are recoded to 100 , giving a uniform scale that ranges from zero to 100 for this variable.

The second measure of school attainment employed in the analysis is one that indicates primary-school completion. This variable is measured for children older than ten and effectively addresses the problem of censoring in measuring school attainment for currently enrolled children by restricting the sample to an age cohort old enough to have completed a certain level of education. Children who are on track in school are expected to have completed a fourth-grade education by the age of 11 , at which point they are considered to have completed the primary level of education in Nepal. This variable is simply coded as one if a child older than ten has a fourth-grade education or higher and zero otherwise. ${ }^{4}$

\section{Explanatory variables}

The nature of parent's work

The main explanatory variables of interest in this study broadly capture the nature of the work of the mother (and father) in the household. Much of the literature on the effects of parental employment on children's welfare in developing countries has focused almost exclusively on maternal labor supply, generally without consideration of the nature of women's work or of the working patterns of fathers (Glick 2002; Glick and Sahn 1998). In this study, I address both of these shortcomings in the literature by delineating both the type of parents' work, primarily that of mothers, using the sector of work as a distinguishing characteristic, and also by accounting for the working patterns of fathers. First, the parents' work sector is distinguished by whether the majority of their work is performed in the agricultural or the nonagricultural sector. This determination is made based on detailed data available concerning the number of hours spent by individuals in different activities categorized as agricultural or nonagricultural in the week, month, or year preceding the survey. This distinction is chosen in preference to an alternative such as formal-versus-informal work, because it is more meaningful in the context of Nepal, a primarily agrarian but rapidly changing economy. The previously discussed time and income effects of the work activity are also more unambiguously determinable for the agriculture/nonagriculture distinction, compared with the formal/informal work distinction. ${ }^{5}$

Second, father's work sector is taken into account in an identical fashion. Given that men's working patterns may influence both the need for women to work, or for women to work in a certain sector, a novel approach is adopted to alleviate any concerns about the issue of multicollinearity between the work-sector variables of a couple entered in a regression. Thus, 
instead of entering them as separate variables in the multivariate regression analyses as is the traditional approach, the independent variables in this study are created as combinations of the dyadic work patterns, resulting in four mutually exclusive categories that indicate parental work schedules as follows:

(a) both mother and father work in the agriculture sector (reference category);

(b) mother works in the agriculture sector; father works in the nonagriculture sector;

(c) mother works in the nonagriculture sector; father works in the agriculture sector; and

(d) both mother and father work in the nonagriculture sector.

In addition to the statistical advantage of this approach, these variables also account for the joint nature of household work decisions that might affect children. Despite the construction of these combination variables, it is worth re-emphasizing that the focus remains on how maternal work affects children's outcomes. The analyses thus will pay special attention, therefore, to how the associations of these combinations with outcomes vary by the type of work the mother performs, while also taking into consideration the father's work sector. The distribution of these work-sector combinations together with that of the mother's and father's individual work- sectors are presented in Table 2. Additionally, mediation analyses, discussed in detail below, pay particular attention to maternal earnings and the mother's share of household income to examine the significance of maternal work characteristics for children. For the reasons discussed above, mothers' influence remains greater than fathers' for children's development, particularly for younger children.

\section{Intermediate variables}

Household income, maternal earnings, and hours of work

A commonly used proxy for permanent household income is employed in this analysis to indicate family income, that is, a variable that measures the nominal expenditure per capita in Nepali rupees (US\$1 = approximately Rs.70.00 in 2008), (see for example, Glick and Sahn 2000 and Maitra 2003). This variable is measured using a set of standard expenditure components described in detail in CBS (2004). The natural log of this variable is used as a regressor and tested for any mediating effects. Typically, data on total expenditures and consumption are considered good proxies for household income in developing countries and are widely used. Expenditures are measured with less error than earnings and also are considered less sensitive than earnings to transitory fluctuations in the economy or the family's economic conditions, because households tend to adjust for such changes relatively smoothly in developing countries (Maitra 2003; CBS 2004).

A measure of maternal earnings as a share of household income is also used in the analyses as a proxy for the mother's control over household income and resources. In order to calculate this measure, annualized earnings of the mother, in cash or in kind, from agricultural and nonagricultural activities are enumerated using detailed data on her earnings from these activities. In order to capture the mother's control over household resources, a ratio of the mother's earnings to total household annual income is measured. Because household expenditure per capita is used as a proxy for income, this variable is ultimately calculated by taking the ratio of the mother's annual earnings to total household annual expenditures. Total household 
expenditure is calculated by multiplying household expenditures per capita by the size of the household (both measures appear in a CBS-created dataset of various household-level indicator variables). This ratio has a minimum value of zero where the mother's earnings are reported as zero. The maximum value of this ratio can exceed one, as in the case of some high-earning mothers, when their earned income exceeds total household expenditures. This variable provides an estimate of the mother's relative contribution to total household resources and indicates her economic status or bargaining power within the household, which might be consequential for children (see Engle 1991; Glick 2002).

Finally, the number of hours worked by the mother in the week preceding the survey is also incorporated in the analyses. Hours of the mother's work, particularly at very high levels are tested for any moderating effects. Thus, a dummy variable indicating high levels of maternal work is measured and coded as one if a mother worked 35 hours or more and coded as zero if she worked less than 35 hours. Mothers working 35 hours or more represent approximately the upper quartile of hours worked by mothers in the cross-sectional households.

\section{Control variables}

The analyses in this paper account extensively for a range of child, parent, family, and household characteristics. The analyses control for childrens' age in years and their sex. A control is also included for the caste or ethnic background of the child. In Nepal, significant disparities have been noted for children and families in terms of their access to schooling or educational opportunities by their ethnic backgrounds (World Bank and DFID 2006). Highercaste groups in the traditional Hindu system, the Brahmins, Chettris, and Newars, are consistently observed to have better outcomes than lower-caste groups, particularly for school enrollment and completion. A variable indicating higher caste is, therefore, included and is coded as one or "higher caste" if household heads fell within the Brahmin, Chettri (both from the Hills and the Terai), or the Newar category. All other castes, which include middle or lower castes, indigenous groups, or the Janajati and the Dalit (formerly the "untouchables") communities (more than 75 different groups), are coded as zero (see World Bank and DFID 2006 for a detailed discussion of the caste system in Nepal and its implications for health and education). Other control variables, which can be broadly categorized in the following groups, represent key confounding influences in these models.

\section{Human capital characteristics of parents}

Variables in parents' human capital characteristics include the age of the household head in years and whether either or both parents suffered from any chronic illnesses. Chronic illnesses, as defined in the NLSS, are prolonged illnesses that affect individuals. These include asthma, heart disease, diabetes, kidney disease, high blood pressure, respiratory problems, and cirrhosis, among others. Mother's and father's schooling are measured separately using a series of dummy variables indicating whether each parent has never attended school, has less than a primaryschool education (less than fourth-grade level), has completed primary school but not secondary school (higher than fourth-grade but less than tenth-grade or the School Leaving Certificate Examination [SLC]), or has completed secondary (higher then tenth-grade or SLC). Parents 
reporting zero years of schooling as their highest grade attained are categorized as not having attended school.

\section{Family size and composition}

For its potential influences for childcare and sibling effects on schooling for boys and girls, several variables indicating family composition are also included as controls in this study. First, a control for the total number of children in the household is included, because siblings tend to compete for limited resources within the household. Additionally, because evidence shows significant negative sibling effects of having very young children in a household, particularly for schooling (for example, see Glick and Sahn 2000), individual dummy variables indicating the presence of children of different age groups in the household are created for children aged $0-4,5-9,10-14$, and 15-19. A measure of whether any additional adults live in the household is also included in the controls. This variable is coded as one if there is at least one adult is in the household other than parents of the child and zero otherwise.

\section{Variables for adequacy of and access to resources}

Data concerning a series of variables that denote the perceived adequacy of certain resources crucial for day-to-day life, such as food, clothing, housing, schooling and health care are available in the NLSS. Among these, a variable indicating the adequacy of schooling, is included in the models for its relevance in predicting schooling outcomes This variable is included as a potential proxy for the accessibility of schooling and is measured as a dummy variable where one represents a response in which respondents said that access to schooling was “adequate” or "more than adequate," and zero represents a response of "less than adequate.” This proxy, which is assumed to be exogenous to the parental work-child outcome relationship is included in all of the schooling regression models presented here.

\section{Regional and household-level variables}

Given the considerable geographical diversity of the terrain in Nepal, which can affect not only access to facilities but also levels of development, modernization, and the economic activity of the population, indicators for the geographic region in which the household is situated are also included. Four mutually exclusive dummy variables are used: mountain, urban hilly, rural hilly (the reference category), and Terai (the southern plains). Finally, a variable indicating whether the household is in an urban area is also included. Because of the predominantly rural nature of the Nepalese population, despite considerable urbanization that took place in the past decade, stratified analyses are not conducted on these distinctions separately because few households fall into the urban category.

\section{METHODS AND EMPIRICAL STRATEGY}

The analyses presented here are conducted primarily with maximum likelihood probit models for dichotomous outcomes and ordinary least squares (OLS) for continuous measures. All models are estimated on a sample of pooled data for children from the NLSS I and NLSS II surveys in a series of sequential models $(\mathrm{N}=7,312)$. A time dummy indicating whether the 
observation for the child is made in NLSS I $(=1)$ or NLSS II $(=0)$ is included to capture any cohort- or time-related effects. In all of the regressions, a base model estimates the associations between parental sectors of work and children's schooling outcomes controlling for a set of exogenous independent variables. Following Baron and Kenny (1986) (see also Holmbeck 2002), sequential models are used to test for the mediating role of (1) household income (proxied by log household expenditure per capita and (2) the ratio of mother's earnings to total household expenditure. These models can be represented by the following equations:

\section{Base model:}

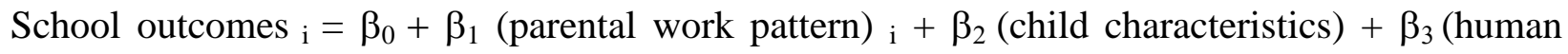
capital characteristics of parents) ${ }_{i}+\beta_{4}$ (family size and composition) ${ }_{i}+\beta_{5}$ (adequacy/access to

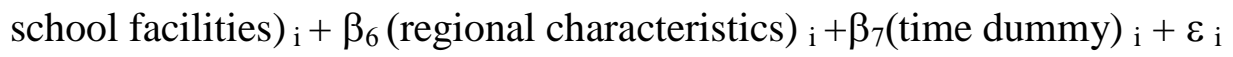

\section{Base model + household income:}

School outcomes $_{i}=\beta_{0}+\beta_{1}$ (parental work pattern) $_{i}+\beta_{2}$ (Log of household expenditure per capita) $+\beta_{3}$ (child's characteristics) $+\beta_{4}$ (parents' human capital characteristics) $i+\beta_{5}$ (family size and composition) ${ }_{i}+\beta_{6}$ (adequacy/access to school facilities) ${ }_{i}+\beta_{7}$ (regional characteristics) $\mathrm{i}+\beta_{8}\left(\right.$ time dummy) $\mathrm{i}+\varepsilon_{\mathrm{i}}$

\section{Base model + mother's share of income:}

School outcomes $_{i}=\beta_{0}+\beta_{1}$ (parental work pattern) ${ }_{i}+\beta_{2}$ (Ratio of mother's earnings to total household expenditures) $+\beta_{3}$ (child's characteristics) $+\beta_{4}$ ( parents' human capital characteristics) ${ }_{i}+\beta_{5}$ (family size and composition) ${ }_{i}+\beta_{6}$ (adequacy/ access to school facilities) ${ }_{i}$ $+\beta_{7}$ (regional characteristics) $_{\mathrm{i}}+\beta_{8}$ (time dummy) $_{\mathrm{i}}+\varepsilon_{\mathrm{i}}$

Additional analyses, as stipulated in Baron and Kenny (1986), which are required to test for mediation, are also run to examine the associations between work-sector variables and the mediators. Interaction models of work-sector combinations with time spent by mother's at work (high intensity $=35+$ hours a week) are also run to examine the moderating effects of the maternal work effort. The regressions are estimated using complete case analysis (listwise deletion) for children with complete data on schooling outcomes and all covariates that appear in individual regressions. Analyses by sex of child are also estimated. Within-household correlation of unobserved factors across children that are characteristic of household data from the developing world is corrected in each of the models by using robust standard errors clustered at the household level by means of the "cluster" function in STATA computer software (Deaton, 1997). Appropriate tests are used to examine the statistical and systematic equality of coefficients, including using Wald tests for the main models and Chow tests for the stratified models. 


\section{RESULTS}

\section{Descriptive results}

The descriptive results are presented in Tables 2 and 3. Table 2 presents the household means and standard deviations of the explanatory variables from the analytical sample of the cross-sectional households of the NLSS I and NLSS II surveys. The analytical sample is comprised of households with children and that do not have missing data on mother's and father's work sector, resulting in a sample of 1,817 households in NLSS I and 1,782 households in NLSS II. ${ }^{6}$ First, in 65 percent of NLSS I households and 58 percent of NLSS II households both parents were working in the agriculture sector. The decline in households where both parents work at agricultural jobs is nontrivial, as expected. Similarly in 21 percent of households in NLSS I and 26 percent of households in NLSS II, mothers were working in the agriculture sector and father's were working in the nonagriculture sector. Households where the mother worked in the nonagriculture sector and the father worked in the agriculture sector represented only a small proportion of the total households, however, with only 2 percent of NLSS I households and 2 percent of NLSS II households falling into this category. Finally, 12 percent of households in NLSS I and 15 percent of households in NLSS II, both parents were working in the nonagriculture sector. These numbers clearly indicate a nontrivial transition into increasingly nonagricultural forms of work for both mothers and fathers.

Among other key household variables in the analytic sample, schooling of both parents showed considerable gains between waves. For example, whereas only 22 percent of fathers and only 6 percent of mothers had completed primary school in NLSS I, these numbers had improved to 26 percent and 11 percent, respectively, in NLSS II. Literacy rates of both mothers and fathers improved in the cross-sectional samples in the period between the two surveys (48 percent to 57 percent for fathers and 12 percent to 22 percent for mothers-not shown). Household expenditure per capita, which is included in the analysis as a proxy for permanent household income, also increased from 8.7 to 9.4 (logged values, and not adjusted for inflation) between waves. Earnings, however, showed increases for fathers (5.7 to 6.1) but small declines for mothers (2.8 to 2.7). Variables indicating the household's perception of adequacy of schooling showed significant improvements with more than 70 percent of households reporting that access to schooling facilities were adequate in 2003-04 compared with only approximately 44 percent of households reporting the same in 1995-96. Finally, 38 percent of households were categorized as poor in the 1995-96 sample, compared with only 28 percent of households in 2003-04.

Table 3 reports the descriptive statistics for some demographic characteristics of children and the dependent variables in the analysis. The average age of children was 9.2 years in NLSS I and 9.8 years in NLSS II. Slightly more than one-half of the sample was male in both waves. Among the outcome variables in schooling, descriptive statistics show that enrollment vastly improved in Nepal in the period between the surveys; more than 85 percent of children had ever attended school and 75 percent of school-aged children were enrolled in school in 2003-04, compared with 71 percent and 62 percent, respectively, in 1995-96. Primary-school completion rates were significantly better in 2003-04 as well, with more than 76 percent of children in the sample who were older than ten completed primary school, compared with 67 percent in 199596. The mean for the grade-for-age variable also showed improvement between the waves (mean 
$=52$ in NLSS I to mean $=66.8$ in NLSS II), indicating that children were increasingly on track in their schooling.

\section{Multivariate analyses}

A series of multivariate regression models ${ }^{7}$ were run to examine the relationship between parental work and schooling among children. Mediating and moderating effects of income, maternal income, and time are also simultaneously examined in these models. For dichotomous outcomes of school enrollment (ever attending school and currently attending school) and completion (whether completed primary school), models are estimated using binary probit regression. For the ease of interpretation, instead of reporting probit coefficients, the tables report marginal effect coefficients obtained from the probit estimation using the dprobit command in STATA computer software. These marginal effect coefficients represent the change in the probability, in percentage points, of the dependent variable being equal to one (ever or currently attending school or completing primary school) with a discrete change in a dichotomous independent regressor (such as the maternal and paternal work-sector variables or sex of the child) or the marginal change in this probability with a unit change in continuous regressors (such as an additional year of age), holding all other variables constant at their respective means. The model for grade-for-age, which is measured on a continuous scale of 1 to 100 , is estimated using simple ordinary least squares.

\section{School enrollment}

The results of the binary probit estimation of the two school-enrollment outcomes: (ever attended school and currently attending school) are reported in Tables 4 and 5. The estimation for these outcomes includes all children of school-going age between the ages of 6 and 19. In the results for maternal and paternal work-sector combinations, both parents' work in the nonagriculture sector appears to be consistently and highly significantly associated with both ever being enrolled in school or being enrolled in school at the time of the survey, compared with results found when both parents work in the agriculture sector. With the exception of one case, all models estimated here, with and without additions of household income and maternal income share variables, showed sustained significant associations with higher probabilities of school enrollment. In the base model, the result when both parents were working in the nonagriculture sector was associated with a 7 percentage point increase in the probability of ever having been enrolled in school $(\mathrm{p}<0.01)$ and a 6 percentage point increase in the probability of having been enrolled in school at the time of the survey $(\mathrm{p}<0.05)$.

The size of the marginal effects coefficients experienced declines with the addition of household income, but only remained significant for the ever-attended school outcome (7 to 5 percentage points; Table 4). Here, I follow Baron and Kenny's (1986) method and use results from a series of regressions showing the significant association of this particular parental worksector combination and household income (see Table 6). This decline indicates a partial mediation effect of household income. Although the association with this work combination remained significant for both of these outcomes with the addition of the mother's earnings share of household expenditures, declines in the coefficient size was not noted, so that any chance of a 
mediating effect of the proxy for maternal control over resources was eliminated. In both cases, the household-income-proxy variable was significantly associated with higher probabilities of school enrollment, and coefficient sizes were generally large, as expected (13 percent for ever having attended school, as shown in Table 4, and 16 percent for currently attending school, as shown in Table 5). Income effects are, therefore, manifested significantly in the results noted here, both in the case of the observed partial mediation effect and in the case where the statistical significance of parental work is dropped with the addition of the income proxy. Among other work combinations, those in which mothers work in the agriculture sector in families with fathers who work in the nonagriculture sector showed a marginally significant association with a higher probability of ever being enrolled in school ( 2 percentage points, $p<0.10$, Table 4 ). This association sustained its significance when maternal income as a share of the household income was added (with an increase in the marginal effects coefficient) but not when household income is added. Other work combinations showed no statistically significant associations with school enrollment throughout the sequential models.

In the analyses indicating school enrollment, results for some other covariates of note appear to confirm the results described in previous studies. Although these results are not presented here in tables, they are available upon request, and I discuss some key results here. In all of the sequential models presented here, boys are found to have a significantly higher probability of school enrollment, compared with girls. This result confirms the documented disadvantage that girls still face in schooling in developing countries, including Nepal. Both father's and mother's level of education, which are included as dummy variables of different levels of education attained, showed consistent and highly significant associations with better school enrollment. The marginal effects coefficient sizes exhibit higher values (that is, higher probabilities of school enrollment) when higher levels of education are attained by both parents (compared with no schooling), with notably higher associations with mother's education level. For example, in the model that includes household income, mother's primary-school completion is associated with a 9 percentage point increase in the probability of children's ever having being enrolled in school, compared with enrollment for those whose mothers had no education. This association size is larger than the significant associations of mother's having less than a primaryschool education (8 percentage points), or father's having completed secondary school, compared with the association with fathers who had no schooling (7 percentage points). (All of the results for parents' schooling level discussed here are significant at the 0.01 level at least). Similarly, better access to schooling also is also consistently associated with better schoolenrollment outcomes throughout the sequential models. Sibling-rivalry effects (as noted in Glick and Sahn 2000 and Maitra 2003) are also evident here; a significantly negative association of the presence of siblings younger than five in the household is found with school enrollment. Children in higher-caste households are also seen to have significantly higher probabilities of ever having been enrolled or of being currently enrolled in school, net of all other variables. These variables confirm much of the literature and knowledge concerning children's schooling in developing countries. The negative associations observed for maternal earnings as a share of the household income (proxied by total household expenditures) for both school-enrollment outcomes fails to confirm, however, the earlier discussion of the positive influences of maternal 
control over resources for investments in children's schooling. This result is notable and is discussed in detail below.

\section{Grade attainment and school completion}

Models are also estimated here for two schooling-attainment outcomes: grade attainment and primary-school completion. In the first set of analyses, grade attainment, which is measured for all children of school-going age is controlled for age with the grade-for-age variable. The estimation of these associations is conducted using OLS for children aged seven or older and are presented in Table 7. The results for the work-sector variables of primary interest resemble results from models for school enrollment showing that having both parents working in the nonagriculture sector is significantly associated higher grade-for-age scores for children of school-going age ( 4 points higher, $\mathrm{p}<0.05$ in the base model). This association loses its significance, however, and the size of the coefficient declined substantially (to 0.5 points) in the model that includes the household-income proxy. As in previous models, the household-income proxy showed a highly significant and positive association with grade-for-age (increase of 14 points, $\mathrm{p}<0.01$ ). These results are, again, an indication of the possibility that the significant association seen in the base model is largely attributable to household-income-related factors. A full mediation effect cannot be established, however, without a significant association between the predictor and the outcome. This association retains its significance, but with an increase in the size of the coefficient in the model in which the ratio of mother's earnings to household expenditure is added ( 4 points higher, $\mathrm{p}<0.05$ ), which eliminates the possibility of mediation here as well.

In the models for primary-school completion, presented in Table 8, which were estimated for children older than ten using binary probit models, no significant associations are seen with parental work-sector-variable combinations. The income proxy and the maternal income-share variables are, however, significant in both models, with maternal earnings share showing negative effects and income showing positive effects. Negative associations with the maternal share of household expenditure, which are uniformly observed with both school-enrollment and attainment outcomes, are particularly noteworthy because they are inconsistent with findings described in the larger literature. The current literature on mothers' preferences for investments of resources and their control over them suggests that a higher share would be expected to have a positive association with schooling outcomes.

Other important covariates that were discussed above in the context of school-enrollment outcomes show fairly consistent and expected associations with grade attainment and school completion, however. As in previous models, boys appear to be at an advantage compared with girls both for being on track in school and for completing primary school. Coefficients for gradefor-age for boys were found to be as much as 12 points higher than those for girls, controlling for other variables. The level of education of mothers and fathers showed expected associations; higher levels of education for fathers were associated with children's higher grade-for-age scores and higher probabilities of completing primary school in all of the sequential models. All results remained highly significant. Coefficients for mothers with some schooling appeared to show the larger associations with these outcomes compared with those for mothers with primary-level or

secondary-level schooling. Schooling adequacy also showed significant associations with both 
outcomes, particularly with increases as great as 10 percentage points in grade-for-age scores when schooling facilities were reported to be adequate, compared with when they were not. As in the previous models, sibling-rivalry effects appear to matter for school completion and grade attainment, showing that having a child in the household younger than five is associated with a decline as great as 9 percentage points in grade-for-age scores and as great as 8 percentage points in lower probability of completing primary school. All of these results confirm the literature reviewed earlier. Regional effects seen for school-enrollment measures were evident in these models as well. Children in the mountainous region, which includes much of the remote areas of Nepal where access to schools can be difficult, fared worse in terms of all schooling outcomes, compared with their peers in the rural hilly region (the reference category).

\section{Time effects of maternal work}

Evidence suggests that mothers' working long hours could be associated with worse outcomes for their children (Adelman 1983; Rabiee and Geissler 1992). A set of interaction models intended to delineate moderating effects of high maternal work effort, defined as working 35 hours or more a week, on the relationship between parents' work combinations and children's schooling outcomes are estimated here as shown in Table 9. Due to the complexity of interpreting interaction coefficients in nonlinear models such as maximum likelihood estimation (MLE) (probit) used in previous models for the dichotomous outcomes, all interaction models reported here are estimated using OLS. The results from these interaction models, which are estimated on the most restrictive specification that includes the mother's-income-to-householdincome ratio, are reported in the table. Results reveal only a few statistically significant interaction effects, however, which are the primary coefficients of interest, suggesting that such moderating time effects do not exist. A significant positive association is shown between mothers' working in the agriculture sector in families with fathers who work in the nonagriculture sector and higher probabilities that children have ever attended school and are currently enrolled in school. Both outcomes are lower for children whose mothers work more than 35 hours a week (interaction coefficients of approximately $-0.3, p<0.05$ for having ever attended school and $-0.2, \mathrm{p}<0.10$ for currently attending school). Similarly, the negative association between the mother's working in the nonagriculture sector in families where the father works in the agriculture sector and their children's primary-school completion is further exacerbated when the mother works full time, compared with when she works less than 35 hours a week (interaction coefficient of approximately 1.2, $\mathrm{p}<0.05$ ). The small number of significant interaction effects noted here, four out of a possible 21 results that were tested, does not, however, provide sufficient evidence to suggest that the time effects of mother's work hours are highly relevant.

\section{Analysis by sex of child}

As shown by the largely disparate gross and net enrollment rates for boys and girls and nontrivial disparities by sex in rates of primary-school completion in Nepal (see UNICEF 2004 and World Bank and DFID 2006), there is strong evidence that boys and girls in Nepal face differential outcomes for school enrollment and completion and differences in parental investments in schooling. In the presence of biases in schooling that favor boys, parents' work 
effort, parents' work sector, and other factors including income and household characteristics likely have differential effects in determining schooling for boys and girls. To test for these disparities, the models for schooling outcomes are estimated separately by sex. Before stratified sample regressions are estimated, however, a series of Chow tests, (Chow 1960) are conducted for all outcomes testing for the systematic variation of associations by sex in the regression models. The results of these Chow tests are reported as a summary in Table 10. These tests employ interactions of each variable with the child's sex (boy) and perform a cumulative test showing that all coefficients are equal to zero (that is, coefficients for each variable are not systematically different according to whether the child is a boy or girl) at a 10 percent (marginal) level of significance. These results indicate that associations of the independent variables systematically vary by sex for all but one schooling outcome, strongly supporting the case for running each of these models separately by sex. As noted above, stratified models are also more favorable than more conventional interaction-based analyses for this paper, because the useful intuition behind interaction effects in linear models do not translate to nonlinear models such as those used here.

In the results shown in Table 11, for the primary work-sector variables of interest, consistent associations between both parents' working in the nonagricultural sector and schooling outcomes are seen for girls but, in a majority of cases, not for boys. The results observed here are noteworthy because they indicate that the associations between children's having parents who work in nonagricultural jobs and those children's higher probabilities of ever having been or currently being enrolled in school or having higher grade-for-age scores are significantly higher for girls compared with boys. For example, having both parents working in nonagricultural jobs is associated with an 12 percentage point and a 10 percentage point increase in the probability that a child will ever have attended school or is currently attending school, respectively, for girls, compared with a 4 percentage point increase in those likelihoods for boys. It is similarly associated with a 6 point increase in the grade-for-age score for girls, compared with a 3 point increase for boys (insignificant results for boys are also considered). A series of post-hoc Chow tests were performed for these results to establish whether these differences were statistically significant. Results from these tests, not presented here, reveal that the differences noted above are all marginally significant at the 10 percent level. A similar trend is also noted for several significant associations seen for the category in which the mother works in the agriculture sector while the father works at a nonagricultural job, showing better outcomes for ever having attended school and for current enrollment for girls, compared with boys. Post-hoc tests indicate that these differences were significant at the 10 percent level as well. Results for other key covariates, including both maternal and paternal education variables and schooling adequacy, generally showed both significant and higher advantages for girls compared with boys. This trend persisted for covariates showing negative associations, such as maternal-tohousehold-income ratio and presence of siblings younger than five in the household, showing that like advantages, disadvantages were also larger for girls than for boys. 


\section{Discussion AND CONCLUSIONS}

The key question of inquiry in this study was to examine whether linkages exist between parental work, particularly that of mothers, in the agriculture or nonagriculture sector, and their children's schooling outcomes in Nepal. The initial hypotheses were guided by the larger literature that primarily links maternal work to children's well-being through the differences in their earnings and time spent with children. The potential roles of these factors as mediators or moderators were also tested for the relationships examined here. The findings from the multivariate analyses, indicate that maternal work in the nonagriculture sector is of significant consequence to children's schooling outcomes, particularly when the father works in that sector as well. This finding is especially clear in preliminary models that did not account for parents' income. A comparison of these results, in the absence of a comparable literature on education, with those in the literature that links mothers' type of work with children's nutrition, shows that these results are largely inconsistent with previous studies, the majority of which do not find clear work-sector effects. For examples, Popkin (1980) did not find significant differences in the Philippines in children's nutritional status according to whether the mother worked at home or outside the home. Occupation-based differences in nutritional outcomes were also largely absent in Smith and colleagues' (1980) analyses for Haiti and Vial and Muchnik’s (1989) analyses for Chile. The generally robust finding of significant associations between these variables found here is, therefore, noteworthy. Other studies, including Engle and Pederson (1989) in Guatemala, found associations of parents' occupational differences with children's nutritional-status outcomes in regressions, but these associations disappeared when controls for the level of household resources were included in the models. These results imply that the initially observed differences might be simply the reflection of differences in income or resources, and they are consistent with the findings of this paper. In a majority of cases, with the sole exception being the ever-having-attended-school outcome, the associations dropped their significance with the addition of the household-income proxy variable. The differences in schooling outcomes of children seen when both parents work in the nonagricultural sector may largely capture differences in household income, suggesting that work-sector effects are largely driven by income (see Glick 2002 for a discussion of this point). Evidence that income is a mediator or a pathway of influence on children's schooling could not be found, however, and was ruled out in a majority of the models examined. In only one instance, as mentioned above, was such an influence detected: in the outcome for ever having attended school.

The analyses for the proxy for mother's bargaining power in the household or her control over resources yielded surprising results that failed to confirm initial hypotheses. Although the previous literature suggests that mothers are more often predisposed than fathers to spend resources in ways that benefit their children and that mothers who control more of their income are more likely than fathers to do so, the results seen here indicate otherwise, showing highly significant negative relationships of higher maternal income-to-household-expenditure ratios with schooling outcomes. These findings, although unexpected, are not completely unfounded, however. As Glick (2002) suggests, a woman's control over income depends on more than her contribution to household income. Culture-specific factors, such as women's standing within households and societies and whether individual incomes are pooled, may affect women's 
control over resources. Although in many African societies incomes are not pooled and women may exercise full control over their own earnings, such is not the case in the South Asian context. In a largely patriarchal society such as that of Nepal where women suffer low status and where all income is pooled, men enjoy exclusive control over monetary resources and decisionmaking. Thus, even her high contributions to the household income might not enhance a woman's economic status within the household. The negative associations demonstrated here also point to another possibility: in predominantly patriarchal societies, where men are the primary breadwinners of the family, a higher ratio of the mother's income to household income might indicate a circumstance where the primary male is unable to provide adequately for his family, perhaps because of illness or disability. Households in such circumstances are likely to be severely constrained financially, so that much is demanded of children for household and childcare-related activities. The negative associations noted here could be a reflection of such effects.

The pattern of regression results for various work combinations with schooling outcomes, appears to provide some evidence that mothers' earnings and their preferences are important for their children's well-being. In all but one of the models tested, results show consistent significant associations only when both parents work in the nonagriculture sector but not when only one parent, typically the father, works outside of agriculture. ${ }^{8}$ Fathers' work in higher-earning nonagricultural jobs, even when they earn a substantial proportion of the household income, may not produce significantly better outcomes for their children's schooling than other parental work situations. Only when the mother works at a nonagricultural job as well are the children of the household more likely to attend and complete school in a timely manner. These outcomes may be the cumulative effect of the higher incomes produced when of both parents' engage in nonagricultural work. They may also be a reflection of the aforementioned maternal preferences that benefit children's welfare when mothers earn significant incomes. Of course, these findings do not imply that fathers are inconsequential to children's well-being. In fact, this study explicitly sought to address or at least control for fathers' influences on their children's welfare. As traditional breadwinners in much of the developing world and with higher rates and levels of participation in the labor force compared with women, men's labor-force decisions, earnings, and time are likely to be important influences on the working patterns of women. Fathers, particularly their work decisions and income are thus likely to be, at least indirectly, significant determinants of children's schooling and other outcomes.

Despite the limited findings concerning the association of parental and maternal work sector with children's educational outcomes and concerning the mediating and moderating roles of the intermediate variables, this study finds consistent relationships between schooling outcomes and a range of parental and household characteristics, including parents' education, household composition, and household income, which confirms much of the literature on determinants of schooling in developing countries (see Behrman and Knowles 1999 for a review of the literature concerning income; see also Glick and Sahn 2000). The associations of schooling outcomes with parents' type of work, education, and income when analyzed by sex are noteworthy. Coefficients were considerably larger in magnitude for girls than for boys, confirming previous studies and demonstrating that additional household resources might benefit girls more than boys. These results, as Behrman and Knowles (1999) suggest, imply that in much 
of the developing world, although schooling for boys is becoming increasingly customary, it is still considered less of a necessity and more of a luxury for girls. These larger coefficient sizes are likely an indication that the probability of attending school is much lower for girls than for boys. Similarly, nontrivial patterns of sibling effects on schooling of children were also consistently evident in these findings, showing that having siblings younger than five in the household was detrimental to a child's school attendance. These results were significant for both boys and girls, but the coefficient sizes were greater for girls. This finding likely attests to the differences in the opportunity cost of girls' time in the home compared with that of boys. Girls often have substantially larger domestic responsibilities than their male siblings, including childcare, in poor households in the developing world. A notable contrast in the findings for Nepal from this study with studies from other developing countries, including Guinea (Glick and Sahn 2000) and Bangladesh (Maitra 2003), is in the finding that both mothers' and fathers' education variables significantly affect the schooling of both boys and girls. The existing literature, including the studies noted above, argues that although fathers' education affects the schooling of children of both sexes, mother's education has a strong influence on educational outcomes for daughters only. In the sex-stratified results however, the findings suggest that although maternal education has an impact on girls' schooling that is stronger than its impact on schooling for boys, higher levels of maternal education predict significantly higher probabilities of attending school for children of both sexes.

Some limitations of this study must be noted. Although the implications of the findings described here are made solely on the basis of the agricultural-versus-nonagricultural distinction in type of work for Nepali women and men, these typologies may not sufficiently capture the diversity of the work that Nepali women engage in or the variable compatibilities of their work with the care of children or investments that women make in building their children's human capital. A study by Levine (1988) using ethnographic data collected in Nepal highlights this point precisely. Levine finds that heavy agricultural work, particularly as performed in the mountainous regions in Nepal, pose significant challenges for women who must care for their infants. These difficulties arise from transportation problems in difficult terrain and clearly illustrate that compatibility with childcare can be heavily dependent on context and is not as unambiguous as these distinctions make them out to be. Similar results have also been noted for traditional family agriculture in general in Doan and Popkin (1993) and Gryboski (1996). Certainly, a detailed analysis considering different occupations or at least using a diverse group of categories that better capture work-family challenges for parents and the full complexity of women's work would be ideal for clarifying the nuances of this question. For the type of dyadic analyses presented here, a large number of categories would, however, present methodological challenges. Such analysis is not without precedent, however. A mixed-methods study by Short and her colleagues (2002) accounts explicitly for the clearly heterogeneous nature of women's work that is context specific to China. In their sample from rural China, the authors distinguish women's work as wage work, fieldwork, and sideline work as the primary categories, which are designated by their varying compatibility with childcare. They further distinguish the nonwage work into subcategories such as full-time and half-time jobs (in agriculture and other sorts of work), full-time agricultural work with no fieldwork, full-time fieldwork with no sideline work, sideline work and sector spanners. These categories not only distinguish between the various 
kinds of nonwage work, but also are powerful indicators of the compatibility of rural Chinese women's work with childcare and household responsibilities. If available for Nepal, such data could provide qualitative insights that would augment the inferences made from the findings of this study.

This study would have also benefitted from the availability of data concerning the quality and availability of substitute caregivers beyond what can be inferred from householdcomposition measures used in the analyses. Information on whether working mothers had access to substitute care, and if they did, whether it came from other members of the household, including older children (which point is addressed here, but is speculative), kin or nonkin support networks, hired domestic help, or even formal childcare, could explain the effects of maternal work on children's well-being more effectively after accounting for these variables.

Despite these limitations, the paper makes significant contributions to the literature on mother's work and children's schooling for Nepal. This paper is the first empirical study to examine maternal (and parental) type of work and its impact on children's educational outcomes using large-scale nationally representative data from Nepal. The three studies describe above, Acharya and Bennett (1983), Levine (1988), and Paolisso et al. (2002), are the only studies that have examined women's work in Nepal explicitly; the 1988 and 2002 studies examine its impact on children in a limited capacity. These studies are also limited by their reliance on small, rural, and unrepresentative samples, and although they make important contributions concerning the nuances of mothers' work and its impacts on their children and families, they are not suited to making policy-relevant arguments. This study's use of nationally representative data and its analysis of relevant schooling outcomes, by contrast, is particularly valuable for informing policies and programs that promote two important goals of the development agenda for Nepal: improving the status of women through paid employment and improving educational outcomes for children, particularly girls. Although overwhelming and unequivocal evidence indicating that type of maternal work affects children's schooling was not found, and although the research literature has failed to yield a consistent finding on this point, the other factors that emerged in the analyses as significant predictors of children's educational outcomes, such as parental earnings and education and household income, provide valuable insight into how these goals may be achieved. In addition to providing evidence related to income and education-related strategies, the discussion of factors such as substitute childcare and women's decisionmaking in the household provides the rationale for further research on these topics. The results of such research are likely to be beneficial in the design of better-targeted policies and the development of innovative programs and initiatives aimed at reducing risks and enhancing benefits for children while empowering women.

Raising the status of women in their households and in society is often viewed as the principal pathway to development in the poor countries of the world. The goal of raising women's status through employment has been a part of the development agenda in Nepal for decades. Raising women's status may also be related to other goals, such as improving children's schooling opportunities, their nutrition, and their well-being and eliminating general poverty. These policies must take into account the conflicts and complementarities of women's work if they are to produce the desired results. The findings of this study and of the larger literature on this topic provide insights into what is of benefit to children and what may be detrimental to 
them. Despite the complexity of the relationships that bind these factors, the development agenda has formally incorporated strategies to benefit children all around the developing world in accord with the Millennium Development Goals framework of the United Nations as the vehicles of change. This study makes significant contributions to two key goals of the MDG framework: achieving universal primary education and eliminating gender disparity in primary and secondary education by 2015. These goals are intrinsically related to the question posed in this paper and interconnected to many of the issues discussed here. Continued research and more focused and targeted studies that help enhance our understanding of these issues are essential to the effort to improving the lives of women, children, and families in developing countries such as Nepal.

\section{NoTES}

1 The most recent unofficial figures (CIA World Factbook 2008) show that nearly onethird of the population is living under the poverty line (US\$1 per person per day). The literacy rate among adults was only 48 percent in 2001, with even lower literacy rates for women at only 35 percent. Infant mortality rates were among the highest in the world with 62 deaths per 1,000 live births (2008 estimate). Predominantly an agricultural economy, close to 40 percent of the gross domestic product (GDP) of Nepal came from farming. Close to 80 percent of the population depends on agriculture to earn a living. According to estimates of the Nepalese government, in 2004 the income per capita of Nepal was US\$240 per annum.

2 Traditionally, the school-going age in Nepal, as in many developing countries in South Asia is between 6 and 18 years. To account for late schooling and possible enrollment in post-secondary forms of schooling, analyses are conducted on this group of children for those aged 6-19.

3 Children typically start school in Nepal at the age of six and children between the age of six and ten are the considered to be of primary-school age. Grade-for-age measures are used only for children aged seven and older. See Database and Development Indicators of the Asian Development Bank (ADB).

4 See Database and Development Indicators of the Asian Development Bank $(A D B)$.Children who complete grade four (and enroll in grade five) of primary school are generally believed to have attained the objectives of primary education by having the basic literacy and numeracy skills that will enable them to continue learning.

5 In addition to the agriculture/nonagriculture and formal/self-employed categories, an additional category, broadly defined as "extended economic activity" was introduced in NLSS II. A direct comparison of the work categories from the first and second waves using the full sample was, therefore, not possible, and individuals reporting extended 
economic activities were excluded from the analyses to maintain comparability between waves.

6 Households that were excluded in the analyses because of the absence of work-sector data for parents did not show significant disadvantages, compared with households included in the analysis. These households, in fact, showed that the mother and father have, on average, higher income, fewer children, lower rates of poverty, and higher levels of education.

7 Alternative specifications using the self-employed versus wage-work categories were also estimated (available from the author upon request). The pattern of significant associations in these results were qualitatively similar to the analyses presented in the paper, with children's outcomes showing negative associations of self-employed work of parents with children's schooling activities, compared with wage work.

8 The situation whereby the mother works at a nonagricultural job and the father works in agriculture does not show significant associations with any of the outcomes tested. This finding may be consequence of this category's being the smallest of those studied because such a situation is rare in Nepal.

\section{REFERENCES}

Acharya, M., and L. Bennett. 1983. "Women and the Subsistence Sector: Economic Participation and Household Decision-making in Nepal.” World Bank Staff Working Paper No. 526.

Adelman, C. 1983. "An analysis of the effect of maternal care and other factors affecting growth of poor children in Lima, Peru.” Johns Hopkins University, School of Hygiene and Public Health. Doctoral dissertation.

Asian Development Bank (ADB). 1999. Country Briefing Paper: Women in Nepal. Kathmandu: ADB

—. Database and Development Indicators of the Asian Development Bank. <http://www.adb.org/statistics/>. Accessed 11 August 2008.

Baron, R.M. and D.A. Kenny. 1986. "The moderator-mediator variable distinction in social psychological research: Conceptual, strategic, and statistical considerations.” Journal of Personality and Social Psychology 51: 1,173-1,182.

Basu, Alaka Malwade. 1993. "Family size and child welfare in an urban slum: Some disadvantages of being poor but modern.” In Cynthia B. Lloyd (ed.), Fertility, Family Size, and Structure: Consequences for Families and Children. New York: Population Council. 
Becker, G. 1965. “A model of the allocation of time.” Economic Journal 75: 493-517.

Behrman, J.R. and J. Knowles. 1999. "Household income and child schooling in Vietnam." The World Bank Economic Review 13(2): 211-256.

Central Bureau of Statistics (CBS). 2004. Nepal Living Standards Survey: Statistical Report 2003/04 , volumes I and II. Kathmandu: National Planning Commission/ His Majesty's Government of Nepal.

- 2003. Population Monograph of Nepal. Volume II. Kathmandu: Nepal Planning Commission/ His Majesty's Government of Nepal.

Central Intelligence Agency. The World Fact Book 2007: Profile on Nepal. <https://www.cia. gov/cia/publications/factbook/geos/np.html>. Accessed 11 August 2008.

Chow, G.C. 1960 "Tests of equality between sets of coefficients in two linear regressions.” Econometrica 28(3): 591-605.

Chutikul, S. 1986. "Malnourished Children: An Economic Approach to the Causes and Consequences in Rural Thailand." East-West Population Institute Paper No. 102.

Deaton, A. 1997. The Analysis of Household Surveys: A Microeconometric Approach to Development Policy. Washington, DC: World Bank.

Deolalikar, A. 1998. Primary and Secondary Education in Kenya: Sector Review. Washington, DC: World Bank.

Doan, Rebecca M. and B.M. Popkin. 1993. “Women’s work and infant care in the Philippines” Social Science \& Medicine 36(3): 297-304.

Duraisamy, P. 1992. "Gender, Intrafamily Allocations of Resources and Child Schooling in South India.” Economic Growth Center Discussion Paper No. 667. New Haven, CT: Yale University.

Duraisamy, P. and R. Malathy. 1991. "Impact of public programs on fertility and gender specific investment in human capital of children in rural India: Cross-sectional and time-series analysis.” In T.P. Schultz (ed.), Research in Population Economics volume 7. Greenwich, CT: JAI Press. Pp. 157-187.

Engle, P.L. 1991. "Maternal work for earnings and childcare strategies: Nutritional effects." Child Development 62: 954-965.

Engle P.L. and M.E. Pedersen. 1989. "Maternal work for earnings and children's nutritional status in urban Guatemala." Ecology of Food and Nutrition 22: 211-223. 
Engle, P.L., M.E. Pedersen, and R. Schmidt. 1985. "The effects of maternal employment on children’s nutritional status and school participation in rural and urbanizing Guatemala.” Report prepared for USAID.

Glick, P. 2002. "Women's Employment and Its Relation to Children's Health and Schooling in Developing Countries: Conceptual Links, Empirical Evidence, and Policies.” Cornell Food and Nutrition Policy Program Working Paper No. 131.

Glick, P., and D. Sahn, 1998. "Maternal labor supply and child nutrition in West Africa.” Oxford Bulletin of Economics and Statistics 60(3): 32-355.

- 2000. "Schooling of girls and boys in a West African country: The effects of parental education, income, and household structure.” Economics of Education Review 19(1): 6387.

Gryboski, K.L. 1996. "Maternal and non-maternal time-allocation to infant care, and care during infant illness in rural Java, Indonesia.” Social Science \& Medicine 43(2): 209-219.

Hoddinott, J. and L. Haddad. 1994. "Women's income and boy-girl anthropometric status in the Côte d’Ivoire.” World Development 22(4): 543-553.

Holmbeck, G.N. 2002. Post-hoc probing of significant moderational and mediational effects in pediatric populations.” Journal of Pediatric Psychology 27(1): 87-96.

Ilahi, Nadeem. 2001. “Children’s Work and Schooling: Does Gender Matter? Evidence from the Peru LSMS.” Background Paper for World Bank Policy Research Report on Gender. Washington, DC: World Bank.

International Monetary Fund (IMF). 2006. “Nepal: Poverty Reduction Strategy Paper Progress Report.” Washington DC: IMF.

Joekes, S. 1989. "Women's work and social support for childcare in the Third World.” In J. Leslie and M. Paolisso, (eds.), Women, Work, and Child Welfare in the Third World. Boulder, CO: Westview Press.

Leslie, J. 1989. "Women's work and child nutrition in the third world.” In J. Leslie and M. Paolisso (eds.), Women, Work, and Child Welfare in the Third World. Boulder, CO: Westview Press. Pp. 19-58.

Leslie, J. and M. Paolisso (eds.). 1989. Women, Work, and Child Welfare in the Third World. Boulder, CO: Westview Press.

Levine, N.E. 1988. “Women’s work and infant feeding: A case from rural Nepal.” Ethnology (27)3: 231-251 
Lokshin, M., E. Glinskaya, and M. Garcia. 2000. “The Effect of Early Childhood Development Programs on Women's Labor Force Participation and Older Children's Schooling in Kenya.” Gender and Development Working Paper Series No. 15. Washington, DC: World Bank.

Maitra, P. 2003. “Schooling and educational attainment: Evidence from Bangladesh.” Education Economics 11(2): 129-153.

Mehra, R. and S. Gammage. 1999. “Trends, countertrends, and gaps in women’s employment.” World Development 27(3): 533-550.

Ministry of Health and Population (MOHP) (Nepal), New ERA, and Macro International (MI). 2006. Nepal Demographic and Health Survey 2006. Kathmandu and Calverton, MD: MOHP, New ERA, and MI.

Nieves, I. 1981. “A balancing act: Strategies to cope with work and motherhood in developing countries." Paper presented at the ICRW Policy Round Table, "The Interface Between Poor Women’s Nurturing Roles and Productive Responsibilities.” Washington, DC: The International Center for Research on Women.

Paolisso, M.J., K. Hallman, L. Haddad, and S. Regmi. 2002. "Does Cash Crop Adoption Detract from Child Care Provision? Evidence from Rural Nepal.” Economic Development and Cultural Change 50: 313-338.

Papart, J. L. 1990. "Wage earning women and the double day: The Nigerian case.” In S. Stichter and J.L. Papart (eds.), Women , Employment and the Family in the International Division of Labour. Philadelphia: Temple University Press.

Patrinos, H. and G. Psacharopolous. 1997. "Family size, schooling and child labor in Peru-An empirical analysis.” Journal of Population Economics 10: 387-405

Popkin, Barry M. 1980. “Time allocation of the mother and child nutrition.” Ecology of Food and Nutrition 9: 1-14.

Rabiee, F., and C. Geissler. 1992. "The impact of maternal workload on child nutrition in rural Iran.” Food and Nutrition Bulletin 14(1): 43-48.

Short, Susan E., Feinian Chen, Barbara Entwisle, and Zhai Fengying. 2002. "Maternal work and time spent in child care in China: A multimethod approach.” Population and Development Review 28(1): 31-57.

Smith, M.F., S.K. Paulsen, W. Fougere, and S.J. Ritchey. 1980. "Socioeconomic, education and health factors influencing growth of rural Haitian children." Ecology of Food and Nutrition 13(3): 99-108. 
Strauss, J. and D. Thomas. 1995. "Human resources: Empirical modeling of household and family decisions.” In T.N. Srinivasan, and J. Behrman (eds.), Handbook of Development Economics, volume 3. Amsterdam: North-Holland Publishing Company.

Thomas, D. 1993. "The distribution of income and expenditure within the household." Annales de Economie et de Statistiques 29: 109-136.

Tuladhar, R. 2005. "Women's participation in Nepal's labor force.” The Economic Journal of Nepal 28(2): 92-103

United Nations Development Programme (UNDP). 2006. Millennium Development Goals Needs Assessment for Nepal. New York: UNDP/ Nepal Planning Commission.

Vial, L. and E. Munchnik. 1989. "Women's market work, infant feeding practices, and infant nutrition among low income women in Santiago, Chile.” In J. Leslie and M. Paolisso (eds.), Women, Work, and Child Welfare in the Third World. Boulder, CO: Westview Press. Pp. 131-149.

Wolfe, B. and J. Behrman. 1982. "Determinants of child mortality, health, and nutrition in a developing country.” Journal of Development Economics 11: 163-194.

World Bank and DFID. 2006. Nepal: Unequal Citizens-Gender, Caste and Ethnic Exclusion in Nepal. (Gender and Social Exclusion Assessment). Kathmandu: World Bank. 
Figure 1 Percentage of economically active population working in agriculture, by sex, Nepal, 1981-2001

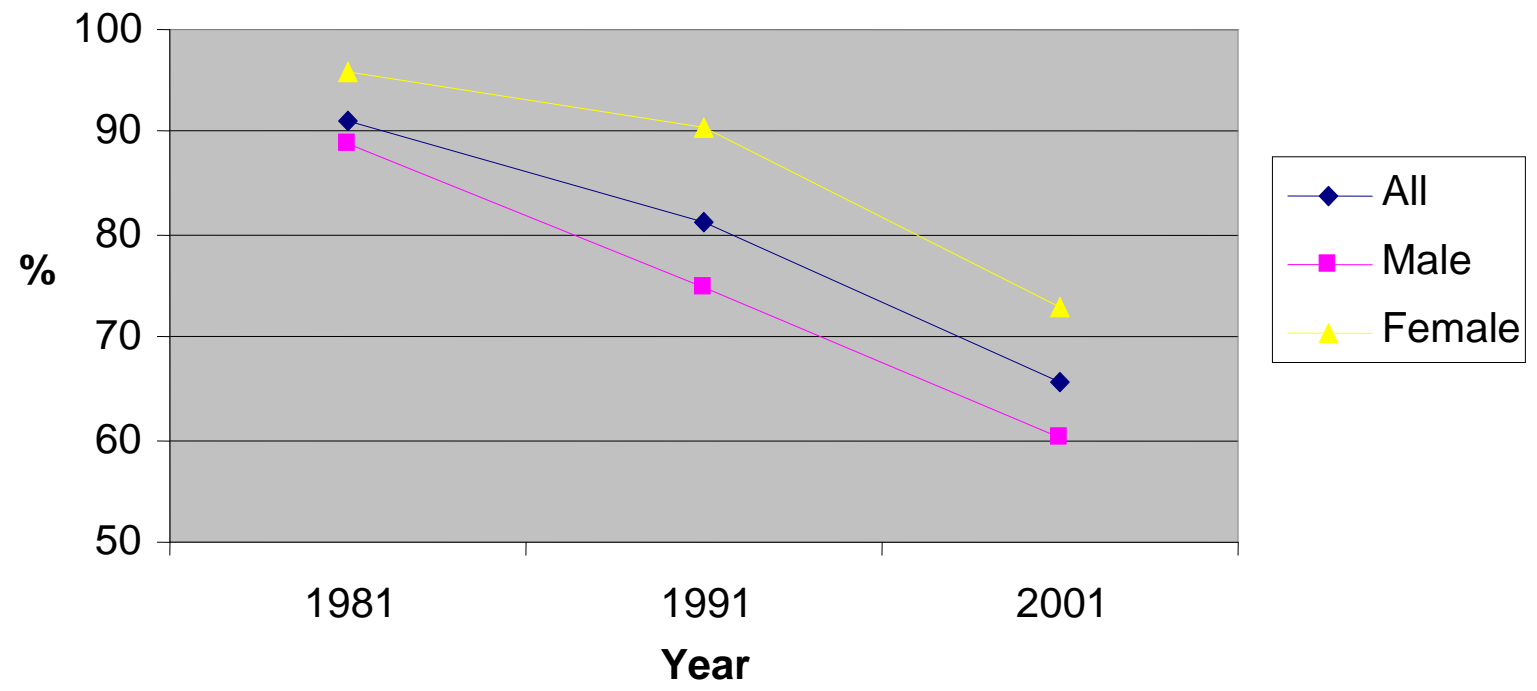


Table 1 Percentage of economically active women in South Asia, by country and region, according to age and national indicators drawn from recent DHS reports

\begin{tabular}{|c|c|c|c|c|c|c|c|}
\hline \multirow{2}{*}{ Variable } & \multirow{2}{*}{$\begin{array}{r}\text { Nepal } \\
\text { DHS } 2006 \\
\end{array}$} & \multirow{2}{*}{$\begin{array}{r}\text { Bangladesh } \\
\text { DHS } 2004 \\
\end{array}$} & \multirow[b]{2}{*}{$\begin{array}{r}\text { Pakistan } \\
\text { DHS 2006-07 }\end{array}$} & \multirow{2}{*}{ Overall } & \multicolumn{3}{|c|}{ India } \\
\hline & & & & & Bihar & $\begin{array}{r}\text { Uttar } \\
\text { Pradesh }\end{array}$ & Raiasthan \\
\hline \multicolumn{8}{|l|}{$\begin{array}{l}\text { Girls and young women } \\
\text { economically active in past } \\
12 \text { months, by age }\end{array}$} \\
\hline 15-19 & 47.8 & 9.9 & 28.8 & 21.9 & 14.5 & 22.5 & 38.3 \\
\hline $20-24$ & 58.9 & 17.1 & 28.0 & 25.6 & 12.4 & 19.1 & 36.8 \\
\hline \multicolumn{8}{|l|}{ National indicators ${ }^{\mathrm{a}}$} \\
\hline Population (in millions) (2006) & 28 & 144 & 159 & 1,110 & na & na & na \\
\hline \multicolumn{8}{|l|}{ Population earning less than } \\
\hline US\$1 a day (per year) & $24.1\left({ }^{\prime} 03\right)$ & $41.3\left({ }^{\circ} 00\right)$ & $17\left({ }^{\prime} 02\right)$ & $34.3\left({ }^{\circ} 04\right)$ & na & na & na \\
\hline Overall GDP (US\$ millions) & 8,052 & 61,961 & 128,830 & 906,268 & na & na & na \\
\hline PPP GNI per capita (2006) & & & & & & & \\
\hline (US\$) & 1,630 & 2,340 & 2,500 & 3,800 & na & na & na \\
\hline
\end{tabular}

na $=$ Not available.

${ }^{a}$ Data are drawn from the World Development Report (2008).

Note: Comparative statistics are based on results from DHS Stat Compiler Results for each country. 
Table 2 Means of explanatory and control household variables, by survey wave, National Living Standards Survey, Nepal, 1995-96 and 2003-04

\begin{tabular}{|c|c|c|c|c|c|c|}
\hline \multirow[b]{2}{*}{ Variable } & \multicolumn{3}{|c|}{ NLSS I } & \multicolumn{3}{|c|}{ NLSS II } \\
\hline & $\begin{array}{r}\text { House- } \\
\text { hold (N) }\end{array}$ & Mean & SD & $\begin{array}{l}\text { House- } \\
\text { hold (N) }\end{array}$ & Mean & SD \\
\hline \multicolumn{7}{|l|}{ Work-sector combination variables of parents (binary variables) } \\
\hline Both mother and father work in agriculture & 1,817 & 0.653 & & 1,782 & 0.580 & \\
\hline Mother's main work is in agriculture, father's main work is nonagricultural & 1,817 & 0.210 & & 1,782 & 0.256 & \\
\hline Mother's main work is nonagricultural, father's main work is in agriculture & 1,817 & 0.017 & & 1,782 & 0.019 & \\
\hline Both mother's and father's work is nonagricultural & 1,817 & 0.121 & & 1,782 & 0.145 & \\
\hline \multicolumn{7}{|l|}{ Work-sector variables of parents (full categories) } \\
\hline Mother's main work is in wage agriculture & 1,817 & 0.111 & & 1,782 & 0.078 & \\
\hline Mother's main work is wage nonagricultural & 1,817 & 0.049 & & 1,782 & 0.051 & \\
\hline Mother's main work is in self-employed agriculture & 1,817 & 0.751 & & 1,782 & 0.759 & \\
\hline Mother's main work is self-employed nonagricultural & 1,817 & 0.089 & & 1,782 & 0.112 & \\
\hline Father's main work is in wage agriculture & 1,817 & 0.139 & & 1,782 & 0.075 & \\
\hline Father's main work is wage nonagricultural & 1,817 & 0.202 & & 1,782 & 0.238 & \\
\hline Father's main work is in self-employed agriculture & 1,817 & 0.531 & & 1,782 & 0.524 & \\
\hline Father's main work is self-employed nonagricultural & 1,817 & 0.128 & & 1,782 & 0.163 & \\
\hline \multicolumn{7}{|l|}{ Human capital variables of parents } \\
\hline Age of household head & 1,817 & 41.071 & 10.903 & 1,782 & 41.805 & 10.487 \\
\hline Either or both parents have a chronic illness & 1,817 & 0.211 & & 1,782 & 0.146 & \\
\hline Father has no schooling & 1,816 & 0.577 & & 1,781 & 0.467 & \\
\hline Father has less than primary schooling & 1,816 & 0.082 & & 1,781 & 0.104 & \\
\hline Father has completed primary school (but not SLC; 10th grade) & 1,816 & 0.224 & & 1,781 & 0.262 & \\
\hline Father has completed secondary school (completed SLC) & 1,816 & 0.117 & & 1,781 & 0.167 & \\
\hline Mother has no schooling & 1,815 & 0.889 & & 1,780 & 0.787 & \\
\hline Mother has less than primary schooling & 1,815 & 0.020 & & 1,780 & 0.046 & \\
\hline Mother has completed primary school (but not SLC; 10th grade) & 1,815 & 0.057 & & 1,780 & 0.111 & \\
\hline Mother has completed secondary school (completed SLC) & 1,815 & 0.033 & & 1,780 & 0.057 & \\
\hline \multicolumn{7}{|l|}{ Parental work-related characteristics and wage earnings } \\
\hline Mother's hours worked per week & 1,817 & 29.392 & 18.965 & 1,752 & 22.363 & 9.318 \\
\hline Father's hours worked per week & 1,817 & 29.357 & 18.886 & 1,710 & 31.093 & 17.525 \\
\hline Log mother's earnings & 1,817 & 2.821 & 4.346 & 1,782 & 2.689 & 4.485 \\
\hline Log father's earnings & 1,817 & 5.749 & 4.995 & 1,782 & 6.140 & 5.373 \\
\hline \multicolumn{7}{|l|}{ Family income and assets } \\
\hline Log nominal household consumption/expenditure per capita & 1,817 & 8.743 & 0.671 & 1,782 & 9.358 & 0.692 \\
\hline Mother's earnings as a share of household expenditure (ratio) & 1,817 & 0.274 & 0.424 & 1,782 & 0.249 & 0.416 \\
\hline \multicolumn{7}{|l|}{ Adequacy of and access to resources } \\
\hline Adequacy of health care $(1=$ adequate; $0=$ not adequate $)$ & 1,557 & 0.439 & & 1,560 & 0.715 & \\
\hline Adequacy of schooling ( $1=$ adequate; $0=$ not adequate $)$ & 1,557 & 0.439 & & 1,560 & 0.715 & \\
\hline \multicolumn{7}{|l|}{ Household size and composition } \\
\hline Number of children & 1,817 & 3.008 & 1.519 & 1,782 & 2.809 & 1.490 \\
\hline $0-4$ years & 1,817 & 0.495 & & 1,782 & 0.393 & \\
\hline 5-9 years & 1,817 & 0.584 & & 1,782 & 0.526 & \\
\hline $10-14$ years & 1,817 & 0.579 & & 1,782 & 0.580 & \\
\hline 15-19 years & 1,817 & 0.425 & & 1,782 & 0.473 & \\
\hline Other adults present in the household & 1,817 & 0.441 & & 1,782 & 0.434 & \\
\hline \multicolumn{7}{|l|}{ Household characteristics } \\
\hline Size & 1,817 & 6.150 & 2.462 & 1,782 & 5.829 & 2.312 \\
\hline Poor (consumption for household size < poverty line) & 1,817 & 0.384 & 0.487 & 1,782 & 0.282 & \\
\hline Urban & 1,817 & 0.131 & 0.337 & 1,782 & 0.223 & \\
\hline Mountain region & 1,817 & 0.127 & 0.333 & 1,782 & 0.116 & \\
\hline Urban hilly region & 1,817 & 0.109 & 0.312 & 1,782 & 0.141 & \\
\hline Rural hilly region & 1,817 & 0.355 & 0.479 & 1,782 & 0.312 & \\
\hline Terai region (southern plains) & 1,817 & 0.409 & 0.492 & 1,782 & 0.431 & \\
\hline
\end{tabular}

SLC = School-leaving certificate. $\quad$ SD = Standard deviation. 
Table 3 Means of children's schooling outcome variables, by survey wave, National Living Standards Survey, Nepal, 1995-96 and 2003-04

\begin{tabular}{|c|c|c|c|c|c|c|}
\hline \multirow[b]{2}{*}{ Variable } & \multicolumn{3}{|c|}{ NLSS I } & \multicolumn{3}{|c|}{ NLSS II } \\
\hline & $\begin{array}{l}\text { lber of } \\
\text { zations }\end{array}$ & Mean & $\begin{array}{l}\text { Standard } \\
\text { deviation }\end{array}$ & $\begin{array}{r}\begin{array}{r}\text { Number of } \\
\text { observations }\end{array} \\
\end{array}$ & Mean & $\begin{array}{l}\text { Standard } \\
\text { deviation }\end{array}$ \\
\hline Age of child & 5,466 & 9.167 & 5.284 & 5,005 & 9.819 & 5.229 \\
\hline Child is boy & 5,466 & 0.532 & 0.499 & 5,005 & 0.527 & 0.499 \\
\hline \multicolumn{7}{|l|}{ Schooling } \\
\hline \multicolumn{7}{|l|}{ School enrollment (age 6-19) } \\
\hline Child has ever attended school & 3,745 & 0.706 & & 3,607 & 0.846 & \\
\hline Child is currently enrolled in school & 3,744 & 0.624 & & 3,607 & 0.746 & \\
\hline \multicolumn{7}{|l|}{ Grade attainment } \\
\hline \multicolumn{7}{|l|}{ Grade-for-age ratio (age 7-19) } \\
\hline Completed primary school (age $11-19$ & 1,609 & 0.671 & & 1,873 & 0.759 & \\
\hline
\end{tabular}


Table 4 Coefficients of parental work-sector variables predicting that children aged 6-19 in crosssectional households have ever attended school, Nepal

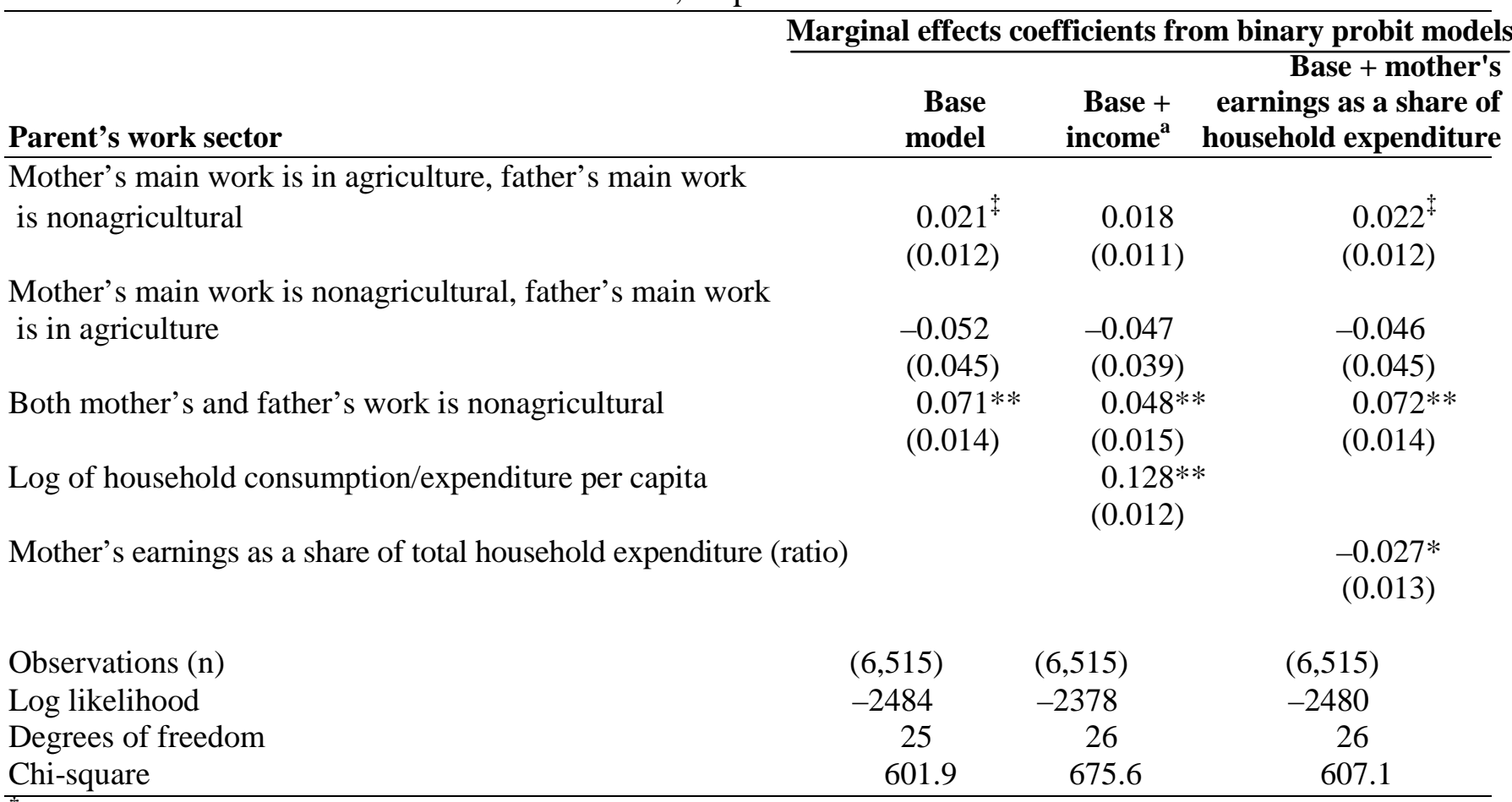

${ }^{\mp}$ Borderline significant at $\mathrm{p}<0.10$. ${ }^{*}$ Significant at $\mathrm{p}<0.05$; ${ }^{* *} \mathrm{p}<0.01$.

${ }^{a}$ Proxied by household expenditure per capita.

Notes: Robust standard errors are given in parentheses. All analyses in these tables control for child's age and sex, household head's age, parental chronic illness, mother's and father's schooling dummy variables, number of children in the household, whether any other adult was present in household, presence in the household of children aged 0-4 years, 5-9 years, 10-14 years, and 15-19 years, whether household is located in an urban area, regional variables, NLSS time dummy, and the adequacy of schooling. 
Table 5 Coefficients of parental work-sector variables predicting that children aged 6-19 in crosssectional households were currently attending school at the time of the survey, Nepal

Marginal effects coefficients from binary probit models Base + mother's

Base Base + earnings as a share of

Parent's work sector model income $^{\text {a }}$ household expenditure

Mother's main work is in agriculture, father's main work is nonagricultural

$0.016 \quad 0.011$

Mother's main work is nonagricultural, father's main work is in agriculture

$\begin{array}{cc}-0.054 & -0.051 \\ (0.050) & (0.046) \\ 0.059^{* *} & 0.026 \\ (0.023) & (0.025) \\ & 0.161^{* *} \\ & (0.015)\end{array}$

$-0.046$

Both mother's and father's work is nonagricultural

Mother's earnings as a share of total household expenditure (ratio)

Log of household consumption/expenditure per capita

$\begin{array}{ccc} & & -0.040^{* *} \\ & & (0.016) \\ & & (6,717) \\ (6,717) & (6,717) & -3182 \\ -3187 & -3092 & 27 \\ 26 & 27 & 820.2 \\ 806.8 & 918.3 & \end{array}$

Observations (n)

Log likelihood

Degrees of freedom

$-3187$

Chi-square

26

918.3

*Significant at $\mathrm{p}<0.05 ; * * \mathrm{p}<0.01$.

${ }^{a}$ Proxied by household expenditure per capita.

Notes: Robust standard errors are given in parentheses. All analyses in these tables control for child's age and sex, household head's age, parental chronic illness, mother's and father's schooling dummy variables, number of children in the household, whether any other adult was present in household, presence in the household of children aged 0-4 years, 5-9 years, 10-14 years, and 15-19 years, whether household is located in an urban area, regional variables, NLSS time dummy, and the adequacy of schooling. 
Table 6 Coefficients of parental work-sector variables predicting intermediate variables, crosssectional households, Nepal

\begin{tabular}{|c|c|c|}
\hline Mediators & $\begin{array}{c}\text { ary least squares reg } \\
\begin{array}{c}\text { Log of household } \\
\text { expenditures } \\
\text { per capita }\end{array} \\
\end{array}$ & $\begin{array}{r}\text { Mother's share of } \\
\text { total household } \\
\text { expenditures }\end{array}$ \\
\hline Mother's main work is in agriculture, father's main work is nonagricultural & $\begin{array}{c}0.011 \\
(0.021)\end{array}$ & $\begin{array}{c}0.023 \\
(0.019)\end{array}$ \\
\hline Mother's main work is nonagricultural, father's main work is in agriculture & $\begin{array}{l}-0.035 \\
(0.068)\end{array}$ & $\begin{array}{l}0.197^{* *} \\
(0.062)\end{array}$ \\
\hline Both mother's and father's work is nonagricultural & $\begin{array}{l}0.254^{* *} \\
(0.035)\end{array}$ & $\begin{array}{l}0.077^{* *} \\
(0.029)\end{array}$ \\
\hline Constant & $\begin{array}{l}9.088 * * \\
(0.061)\end{array}$ & $\begin{array}{l}0.522 * * \\
(0.049)\end{array}$ \\
\hline $\begin{array}{l}\text { Observations (n) } \\
\text { R-square }\end{array}$ & $\begin{array}{c}(10,288) \\
0.566\end{array}$ & $\begin{array}{c}(10,288) \\
0.111\end{array}$ \\
\hline
\end{tabular}

**Significant at $\mathrm{p}<0.01$.

Notes: Robust standard errors are given in parentheses. All analyses in these tables control for child's age and sex, household head's age, parental chronic illness, mother's and father's schooling dummy variables, number of children in the household, whether any other adult was present in household, presence in the household of children aged 0-4 years, 5-9 years, 10-14 years, and 15-19 years, whether household is located in an urban area, regional variables, and NLSS time dummy. 
Table 7 Coefficients of parental work-sector variables predicting grade-for-age scores for all children aged 7-19 in cross-sectional households, Nepal

\begin{tabular}{|c|c|c|c|}
\hline \multirow[b]{2}{*}{ Parent's work sector } & \multicolumn{3}{|c|}{ Ordinary least squares regression coefficients } \\
\hline & $\begin{array}{r}\text { Base } \\
\text { model }\end{array}$ & $\begin{array}{r}\text { Base }+ \\
\text { income }^{\text {a }}\end{array}$ & $\begin{array}{r}\text { Base }+ \text { mother's } \\
\text { earnings as a share of } \\
\text { household expenditure }\end{array}$ \\
\hline $\begin{array}{l}\text { Mother's main work is in agriculture, father's main work } \\
\text { is nonagricultural }\end{array}$ & $\begin{array}{c}1.752 \\
(1.340)\end{array}$ & $\begin{array}{c}1.199 \\
(1.318)\end{array}$ & $\begin{array}{l}1.850 \\
(1.329)\end{array}$ \\
\hline $\begin{array}{l}\text { Mother's main work is nonagricultural, father's main work } \\
\text { is in agriculture }\end{array}$ & $\begin{array}{c}-3.882 \\
(3.748)\end{array}$ & $\begin{array}{c}-3.620 \\
(3.380)\end{array}$ & $\begin{array}{c}-2.934 \\
(3.768)\end{array}$ \\
\hline Both mother's and father's work is nonagricultural & $\begin{array}{r}3.819^{*} \\
(1.661)\end{array}$ & $\begin{array}{c}0.528 \\
(1.647)\end{array}$ & $\begin{array}{r}4.229^{*} \\
(1.642)\end{array}$ \\
\hline Log of household consumption/expenditure per capita & & $\begin{array}{l}13.767 * * \\
(1.045)\end{array}$ & \\
\hline Mother's earnings as a share of total household expenditure (ratio) & & & $\begin{array}{l}-5.212^{* *} \\
(1.437)\end{array}$ \\
\hline Constant & $\begin{array}{l}62.223^{* *} \\
(4.507)\end{array}$ & $\begin{array}{l}-63.212 * * \\
(10.498)\end{array}$ & $\begin{array}{l}65.493^{* *} \\
(4.572)\end{array}$ \\
\hline Observations (n) & $(6,166)$ & $(6,166)$ & $(6,166)$ \\
\hline R-square & 0.286 & 0.316 & 0.288 \\
\hline
\end{tabular}

*Significant at $\mathrm{p}<0.05 ; * * \mathrm{p}<0.01$.

${ }^{a}$ Proxied by household expenditure per capita.

Notes: Robust standard errors are given in parentheses. All analyses in these tables control for child's age and sex, household head's age, parental chronic illness, mother's and father's schooling dummy variables, number of children in the household, whether any other adult was present in household, presence in the household of children aged 0-4 years, 5-9 years, 10-14 years, and 15-19 years, whether household is located in an urban area, regional variables, NLSS time dummy, and the adequacy of schooling. 
Table 8 Coefficients of parental work-sector variables predicting primary-school completion for all children aged 11-19 in cross-sectional households, Nepal

Marginal effects coefficients from binary probit models Base + mother's

Base $\quad$ Base + earnings as a share of

Parent's work sector model income $^{\text {a }}$ household expenditure

Mother's main work is in agriculture, father's main work is nonagricultural

$0.006 \quad 0.002$

$(0.023) \quad(0.023)$

Mother's main work is nonagricultural, father's main work is in agriculture

$\begin{array}{cc}-0.047 & -0.056 \\ (0.071) & (0.068) \\ 0.013 & -0.012 \\ (0.034) & (0.034) \\ & 0.144^{* *} \\ & (0.019)\end{array}$

$-0.036$

Both mother's and father's work is nonagricultural

Log of household consumption/expenditure per capita

Mother's earnings as a share of total household expenditure (ratio)

Observations (n)

Log likelihood

$\begin{array}{ll}(3,312) & (3,312) \\ -1551 & -1554 \\ 26 & 27 \\ 18.7 & 552.6\end{array}$

Degrees of freedom 518.7

Chi-square

552.6

529.3

*Significant at $\mathrm{p}<0.05 ; * * \mathrm{p}<0.01$.

${ }^{a}$ Proxied by household expenditure per capita.

Notes: Robust standard errors are given in parentheses. All analyses in these tables control for child's age and sex, household head's age, parental chronic illness, mother's and father's schooling dummy variables, number of children in the household, whether any other adult was present in household, presence in the household of children aged 0-4 years, 5-9 years, 10-14 years, and 15-19 years, whether household is located in an urban area, regional variables, NLSS time dummy, and the adequacy of schooling. 
Table 9 Coefficients of parental work-sector variables and interaction with mother's hours of work predicting children's schooling outcomes, cross sectional households, Nepal

\begin{tabular}{|c|c|c|c|c|}
\hline \multirow[b]{2}{*}{ Parents' work sector } & \multicolumn{4}{|c|}{ Marginal effects coefficients from binary probit models } \\
\hline & $\begin{array}{r}\text { Ever } \\
\text { attended } \\
\text { School }\end{array}$ & $\begin{array}{r}\text { Currently } \\
\text { attending } \\
\text { school }\end{array}$ & $\begin{array}{r}\text { Completed } \\
\text { primary } \\
\text { school }\end{array}$ & $\begin{array}{l}\text { Grade } \\
\text { for age }\end{array}$ \\
\hline Mother works 35+ hours per week & $\begin{array}{c}0.034 \\
(0.076)\end{array}$ & $\begin{array}{c}0.104 \\
(0.067)\end{array}$ & $\begin{array}{c}0.066 \\
(0.091)\end{array}$ & $\begin{array}{c}0.414 \\
(1.743)\end{array}$ \\
\hline Mother's main work is in agriculture, father's main work is nonagricultural & $\begin{array}{c}0.178 * \\
(0.074)\end{array}$ & $\begin{array}{c}0.112^{f} \\
(0.062)\end{array}$ & $\begin{array}{c}0.058 \\
(0.089)\end{array}$ & $\begin{array}{c}2.329 \\
(1.489)\end{array}$ \\
\hline Mother's main work is in agriculture, father's is nonagricultural X mother works 35+ hours per week & $\begin{array}{c}-0.297^{*} \\
(0.140)\end{array}$ & $\begin{array}{c}-0.241^{\neq} \\
(0.126)\end{array}$ & $\begin{array}{c}-0.072 \\
(0.166)\end{array}$ & $\begin{array}{c}-2.760 \\
(3.019)\end{array}$ \\
\hline Mother's main work is nonagricultural, father's main work is in agriculture & $\begin{array}{c}-0.160 \\
(0.199)\end{array}$ & $\begin{array}{c}-0.064 \\
(0.158)\end{array}$ & $\begin{array}{c}-0.024 \\
(0.247)\end{array}$ & $\begin{array}{c}-1.302 \\
(4.021)\end{array}$ \\
\hline Mother's main work is nonagricultural, father's is in agriculture X mother works 35+ hours per week & $\begin{array}{c}-0.285 \\
(0.524)\end{array}$ & $\begin{array}{c}-0.604 \\
(0.590)\end{array}$ & $\begin{array}{c}-1.227^{*} \\
(0.552)\end{array}$ & $\begin{array}{c}-17.225 \\
(11.004)\end{array}$ \\
\hline Both mother's and father’s work is nonagricultural & $\begin{array}{l}0.457^{* *} \\
(0.133)\end{array}$ & $\begin{array}{c}0.252^{*} \\
(0.105)\end{array}$ & $\begin{array}{c}0.081 \\
(0.132)\end{array}$ & $\begin{array}{c}5.439 * * \\
(1.902)\end{array}$ \\
\hline Both mother's and father's work is nonagricultural X mother works 35+ hours per week & $\begin{array}{c}-0.072 \\
(0.224)\end{array}$ & $\begin{array}{c}-0.131 \\
(0.196)\end{array}$ & $\begin{array}{c}-0.148 \\
(0.201)\end{array}$ & $\begin{array}{l}-4.212 \\
(2.783)\end{array}$ \\
\hline Mother's earnings as a share of total household expenditure (ratio) & $\begin{array}{c}-0.138^{*} \\
(0.067)\end{array}$ & $\begin{array}{c}-0.131^{*} \\
(0.057)\end{array}$ & $\begin{array}{c}-0.175^{*} \\
(0.082)\end{array}$ & $\begin{array}{c}-5.296 * * \\
(1.457)\end{array}$ \\
\hline Constant & $\begin{array}{c}0.167 \\
(0.214)\end{array}$ & $\begin{array}{l}1.096^{* *} \\
(0.184)\end{array}$ & $\begin{array}{c}-2.275^{* *} \\
(0.333)\end{array}$ & $\begin{array}{l}64.494 * * \\
(4.607)\end{array}$ \\
\hline Observations (n) & $(6,465)$ & $(6,667)$ & $(3,283)$ & $(6,118)$ \\
\hline Log likelihood & -2461 & -3151 & -1528 & \\
\hline Degrees of freedom & 30 & 31 & 31 & \\
\hline Chi-Square & 607.4 & 830.9 & 532.8 & \\
\hline R-Square & & & & 0.290 \\
\hline
\end{tabular}

${ }^{\mp}$ Borderline significant at $\mathrm{p}<0.10$. *Significant at $\mathrm{p}<0.05 ; * * \mathrm{p}<0.01$.

Notes: Robust standard errors are given in parentheses. All analyses in these tables control for child's age and sex, household head's age, parental chronic illness, mother's and father's schooling dummy variables, number of children in the household, whether any other adult was present in household, presence in the household of children aged 0-4 years, 5-9 years, 10-14 years, and 15-19 years, whether household is located in an urban area, regional variables, NLSS time dummy, and the adequacy of schooling. 
Table 10 Chow test results for regressions of school enrollment and grade attainment, stratified by sex and age for children in cross-sectional households, using interactions, Nepal

By sex (boy versus girl)

Variable

Significant $\quad$ Significance level

School enrollment (ages 6-19)

Child has ever attended school

Child is currently enrolled in school

No

$\mathrm{X}$

Yes

$* *$

Grade attainment

Grade-for-age ratio (7-19) (range $=0-100)$

Yes **

Completed primary school (ages 11-19)

Yes

$*$

*Significant at $\mathrm{p}<0.05 ;{ }^{* *} \mathrm{p}<0.01$.

Note: Chow tests: Coefficients systematically differ by stratification variable. Tests all interaction parameters with stratification variable $=0$ for significance. 
Table 11 Parental work-sector variables predicting outcomes for children in cross-sectional households, by sex, from full model, Nepal

\begin{tabular}{|c|c|c|c|c|c|c|c|c|}
\hline \multirow[b]{3}{*}{ Parents' work sector } & \multirow{2}{*}{\multicolumn{2}{|c|}{$\begin{array}{c}\text { Ever attended school } \\
\text { Marginal effects probit } \\
\end{array}$}} & \multirow{2}{*}{\multicolumn{2}{|c|}{$\begin{array}{c}\text { Currently } \\
\text { attending school } \\
\text { Marginal effects probit }\end{array}$}} & \multirow{2}{*}{\multicolumn{2}{|c|}{$\begin{array}{c}\text { Grade-for-age score } \\
\text { OLS coefficient } \\
\end{array}$}} & \multirow{2}{*}{\multicolumn{2}{|c|}{$\begin{array}{c}\text { Completed } \\
\text { primary school }\end{array}$}} \\
\hline & & & & & & & & \\
\hline & Boy & Girl & Boy & Girl & Boy & Girl & Boy & Girl \\
\hline $\begin{array}{l}\text { Mother's main work is in agriculture, father's main } \\
\text { work is nonagricultural }\end{array}$ & $\begin{array}{c}0.004 \\
(0.011)\end{array}$ & $\begin{array}{c}0.049^{*} \\
(0.021)\end{array}$ & $\begin{array}{l}-0.001 \\
(0.018)\end{array}$ & $\begin{array}{c}0.050^{*} \\
(0.025)\end{array}$ & $\begin{array}{c}1.228 \\
(1.498)\end{array}$ & $\begin{array}{c}2.958 \\
(1.943)\end{array}$ & $\begin{array}{l}-0.002 \\
(0.028)\end{array}$ & $\begin{array}{r}0.032 \\
(0.032)\end{array}$ \\
\hline $\begin{array}{l}\text { Mother's main work is nonagricultural, father's main } \\
\text { work is in agriculture }\end{array}$ & $\begin{array}{l}-0.023 \\
(0.039)\end{array}$ & $\begin{array}{l}-0.079 \\
(0.077)\end{array}$ & $\begin{array}{l}-0.045 \\
(0.055)\end{array}$ & $\begin{array}{l}-0.040 \\
(0.072)\end{array}$ & $\begin{array}{l}-2.473 \\
(4.288)\end{array}$ & $\begin{array}{l}-4.067 \\
(5.553)\end{array}$ & $\begin{array}{l}-0.135 \\
(0.095)\end{array}$ & $\begin{array}{r}0.095 \\
(0.078)\end{array}$ \\
\hline Both mother’s and father’s work is nonagricultural & $\begin{array}{l}0.042^{* *} \\
(0.013)\end{array}$ & $\begin{array}{l}0.119 * * \\
(0.026)\end{array}$ & $\begin{array}{c}0.036 \\
(0.027)\end{array}$ & $\begin{array}{l}0.098 * * \\
(0.036)\end{array}$ & $\begin{array}{c}2.913 \\
(1.880)\end{array}$ & $\begin{array}{r}5.684^{*} \\
(2.330)\end{array}$ & $\begin{array}{c}0.015 \\
(0.042)\end{array}$ & $\begin{array}{r}0.030 \\
(0.043)\end{array}$ \\
\hline $\begin{array}{l}\text { Mother's earnings as a share of total household } \\
\text { expenditure (ratio) }\end{array}$ & $\begin{array}{l}-0.010 \\
(0.012)\end{array}$ & $\begin{array}{c}-0.051^{*} \\
(0.024)\end{array}$ & $\begin{array}{c}-0.028 \\
(0.018)\end{array}$ & $\begin{array}{c}-0.066^{*} \\
(0.026)\end{array}$ & $\begin{array}{c}-4.222^{*} \\
(1.676)\end{array}$ & $\begin{array}{l}-6.696 * * \\
(2.030)\end{array}$ & $\begin{array}{l}-0.044 \\
(0.029)\end{array}$ & $\begin{array}{r}-0.077^{*} \\
(0.035)\end{array}$ \\
\hline Constant & & & & & $\begin{array}{l}79.572 * * \\
(5.287)\end{array}$ & $\begin{array}{l}67.043^{* *} \\
(6.536)\end{array}$ & & \\
\hline Observations (n) & $(3,477)$ & $(3,038)$ & $(3,575)$ & $(3,037)$ & $(3,280)$ & $(2,886)$ & $(1,925)$ & $(1,387)$ \\
\hline Log likelihood & -1059 & -1403 & -1571 & -1578 & & & -898.6 & -628.8 \\
\hline Degrees of freedom & 25 & 25 & 26 & 25 & & & 26 & 26 \\
\hline Chi-Square & 249.6 & 324.6 & 449.2 & 440.8 & & & 318.2 & 262.4 \\
\hline R-Square & & & & & 0.228 & 0.329 & & \\
\hline
\end{tabular}

*Significant at $\mathrm{p}<0.05 ; * * \mathrm{p}<0.01$. OLS $=$ Ordinary least squares.

Notes: Robust standard errors are given in parentheses. All analyses in these tables control for child's age and sex, household head's age, parental chronic illness, mother's and father's schooling dummy variables, number of children in the household, whether any other adult was present in household, presence in the household of children aged 0-4 years, 5-9 years, 10-14 years, and 15-19 years, whether household is located in an urban area, regional variables, NLSS time dummy, and the adequacy of schooling. 


\section{Recent Poverty, Gender, and Youth Working Papers}

Working papers are distributed electronically. When a new paper is published, subscribers are notified by e-mail and a link to the paper is provided.

To subscribe to the Poverty, Gender, and Youth working paper e-mail notification list, please send your request to pgywp@popcouncil.org.

PDFs of working papers are available at www.popcouncil.org/publications/wp/index.html

2010

21

Ashish Bajracharya, "The nature of mothers' work and children's schooling in Nepal: The influence of income and time effects.”

$20 \quad$ John Bongaarts, "The causes of educational differences in fertility in sub-Saharan Africa.”

19 Ashish Bajracharya and Sajeda Amin, "Poverty, marriage timing, and transitions to adulthood in Nepal: A longitudinal analysis using the Nepal Living Standards Survey.”

2009

18 Sajeda Amin and Bussarawan Teerawichitchainan, "Ethnic fertility differentials in Vietnam and their proximate determinants.”

17 Sajeda Amin and S. Chandrasekhar, "Looking beyond universal primary education: Gender differences in time use among children in rural Bangladesh.”

16 John Bongaarts, François Pelletier, and Patrick Gerland, "Global trends in AIDS mortality.”

15 Bussarawan Teerawichitchainan and Sajeda Amin, "The role of abortion in the last stage of fertility decline in Vietnam.”
14 Cynthia B. Lloyd and Paul C. Hewett, "Educational inequalities in the midst of persistent poverty: Diversity across Africa in educational outcomes.”

13 Wendy Baldwin and Judith Diers, "Demographic data for development in sub-Saharan Africa.”

\section{8}

12 Sajeda Amin and Lopita Huq, "Marriage considerations in sending girls to school in Bangladesh: Some qualitative evidence.”

11 S. Chandrasekhar and Abhiroop Mukhopadhyay, "Multiple dimensions of urban well-being: Evidence from India”

10 Sajeda Amin and Luciana Suran, "Terms of marriage and time-use patterns of young wives: Evidence from rural Bangladesh.”

9 John Bongaarts, Thomas Buettner, Gerhard Heilig, and François Pelletier, "Has the HIV epidemic peaked?” 
8 Barbara S. Mensch, Paul C. Hewett, Richard Gregory, and Stephane

Helleringer, "Sexual behavior and STI/HIV status among adolescents in rural Malawi: An evaluation of the effect of interview mode on reporting."

7 John Bongaarts, "Fertility transitions in developing countries: Progress or stagnation?” 